\title{
Effect of forage conservation method on plasma lipids, mammary lipogenesis, and milk fatty acid composition in lactating cows fed diets containing a 60:40 forage-to-concentrate ratio
}

\author{
A. Halmemies-Beauchet-Filleau, ${ }^{*} \dagger$ P. Kairenius, ${ }^{*}$ S. Ahvenjärvi, ${ }^{*}$ V. Toivonen, ${ }^{*}$ P. Huhtanen, $¥$ A. Vanhatalo, $\dagger$ \\ D. I. Givens, $\S$ and K. J. Shingfield ${ }^{* 1}$ \\ ${ }^{*}$ MTT Agrifood Research Finland, Animal Production Research, FI-31600 Jokioinen, Finland \\ †University of Helsinki, Department of Agricultural Sciences, PO Box 28, FI-00014 University of Helsinki, Finland \\ $\ddagger$ Swedish University of Agricultural Sciences, Department of Animal Science, S-90183 Umeå, Sweden \\ §University of Reading, School of Agriculture, Policy and Development, Animal Science Research Group, PO Box 236, Reading, \\ RG6 6AT, United Kingdom
}

\begin{abstract}
The effects of forage conservation method on plasma lipids, mammary lipogenesis, and milk fat were examined in 2 complementary experiments. Treatments comprised fresh grass, hay, or untreated (UTS) or formic acid treated silage (FAS) prepared from the same grass sward. Preparation of conserved forages coincided with the collection of samples from cows fed fresh grass. In the first experiment, 5 multiparous Finnish Ayrshire cows ( $229 \mathrm{~d}$ in milk) were used to compare a diet based on fresh grass followed by hay during 2 consecutive 14-d periods, separated by a 5-d transition during which extensively wilted grass was fed. In the second experiment, 5 multiparous Finnish Ayrshire cows (53 $\mathrm{d}$ in milk) were assigned to 1 of 2 blocks and allocated treatments according to a replicated $3 \times 3$ Latin square design, with 14-d periods to compare hay, UTS, and FAS. Cows received 7 or $9 \mathrm{~kg} / \mathrm{d}$ of the same concentrate in experiments 1 and 2, respectively. Arterial concentrations of triacylglycerol (TAG) and phospholipid were higher in cows fed fresh grass, UTS, and FAS compared with hay. Nonesterified fatty acid (NEFA) concentrations and the relative abundance of 18:2n- 6 and 18:3n-3 in TAG of arterial blood were also higher in cows fed fresh grass than conserved forages. On all diets, TAG was the principle source of fatty acids (FA) for milk fat synthesis, whereas mammary extraction of NEFA was negligible, except during zero-grazing, which was associated with a lower, albeit positive calculated energy balance. Mammary FA uptake was higher and the synthesis of 16:0 lower in cows fed fresh grass than hay. Conservation of grass by drying or ensiling had no influence on mammary extraction of TAG and NEFA, despite an increase in milk fat secretion for silages com-
\end{abstract}

Received January 13, 2013.

Accepted May 1, 2013.

${ }^{1}$ Corresponding author: kevin.shingfield@mtt.fi pared with hay and for FAS than UTS. Relative to hay, milk fat from fresh grass contained lower 12:0, 14:0, and 16:0 and higher S3,R7,R11,15-tetramethyl-16:0, cis-9 18:1, trans-11 18:1, cis-9,trans-11 18:2, 18:2n-6, and 18:3n-3 concentrations. Even though conserved forages altered mammary lipogenesis, differences in milk FA composition were relatively minor, other than a higher enrichment of S3,R7,R11,15-tetramethyl-16:0 in milk from silages compared with hay. In conclusion, differences in milk fat composition on fresh grass relative to conserved forages were associated with a lower energy balance, increased uptake of preformed FA, and decreased synthesis of 16:0 de novo in the mammary glands, in the absence of alterations in stearoyl-coenzyme A desaturase activity.

Key words: forage conservation, plasma lipid, milk fat composition, mammary lipogenesis

\section{INTRODUCTION}

Milk fat is a major source of SFA and contributes to trans FA (TFA) in the human diet (Hulshof et al., 1999; Kris-Etherton et al., 2000). A high consumption of SFA and TFA are known risk factors for cardiovascular disease (WHO, 2003), with the risk associated with TFA being higher than SFA (Shingfield et al., 2008). However, evidence on the role of specific isomers of TFA on the onset and development of cardiovascular diseases remains inconclusive (Shingfield et al., 2008; Bendsen et al., 2011). Furthermore, excessive intakes of SFA may also be associated with lowered insulin sensitivity, which is a key factor in the development of the metabolic syndrome and diabetes (Funaki, 2009). In an attempt to lower the economic and social burden of chronic diseases, considerable interest exists in developing sustainable nutritional strategies to lower SFA in milk, 12:0, 14:0, and, 16:0 in particular, and increase cis-9 18:1, cis-9,trans-11 conjugated linoleic acid (CLA), and 18:3n-3 concentrations to improve 
long-term human health (Gebauer et al., 2006; Shingfield et al., 2008). Ruminant milk also contains diastereomers of 3,7,11,15-tetramethyl-16:0 derived from the metabolism of chlorophyll in the rumen (Schröder and Vetter, 2011) that may be beneficial in the treatment of diabetes and obesity in humans (Schlüter et al., 2002).

Depending on the production system, fresh or conserved forages typically contribute to 25 to $100 \%$ of the energy requirements of lactating cows. Despite relatively low lipid content, forages contain high proportions of 18:2n-6 and 18:3n-3, and may often represent the principle source of FA in the diet (Harfoot and Hazlewood, 1988). Milk from grazing cows is known to contain lower proportions of medium-chain SFA and higher unsaturated FA concentrations compared with that from cows fed diets based on dried or ensiled forages (Dewhurst et al., 2006; Elgersma et al., 2006; Chilliard et al., 2007). Available data suggest that the effects of forage conservation on milk fat composition are not explained solely by differences in dietary FA intake. Compared with silage, milk from hay-based diets often has higher concentrations of $18: 2 n-6$ and 18:3n-3, in spite of much lower intakes of 18-carbon PUFA (Dewhurst et al., 2006). On the basis of changes in milk fat from pasture compared with diets based on grass or maize silage, it has been suggested that metabolic and hormonal factors may also contribute to the effects of forage conservation on milk FA composition via direct effects on mammary lipid metabolism (Lock and Garnsworthy, 2003).

The aim of the present study was to examine the influence of forage conservation method on circulating plasma lipids, mammary lipogenesis, and milk fat composition in lactating cows fed diets based on fresh or conserved grasses prepared simultaneously from the same swards of timothy and meadow fescue. Chemical composition of dietary ingredients and treatment effects on intake, rumen fermentation characteristics, FA flow at the omasum, and rumen microbial ecology are reported in a companion paper (Halmemies-BeauchetFilleau et al., 2013).

\section{MATERIALS AND METHODS}

\section{Animals, Experimental Design, and Experimental Diets}

All procedures involving animals were approved by the Animal Experiment Committee of MTT Agrifood Research Finland in accordance with the Use of Vertebrates for Scientific Purposes Act of 1985. Five multiparous lactating Finnish Ayrshire cows $(605 \pm 25.7$ $\mathrm{kg}$ of BW and $229 \pm 31.7$ DIM) were used in the first experiment. Another group of 5 Finnish Ayrshire cows
$(617 \pm 25.8 \mathrm{~kg}$ of BW and $53 \pm 5.3 \mathrm{DIM})$ were recruited to the second experiment. In experiment 1,3 cows were pregnant $(60,76$, and $87 \mathrm{~d}$ of gestation), whereas none recruited to experiment 2 were pregnant. Cows were housed in a dedicated metabolism unit fitted with individual stalls with continuous access to fresh water and milked twice daily at 0700 and $1645 \mathrm{~h}$.

A detailed description of the experimental design and treatments is provided in a companion paper (Halmemies-Beauchet-Filleau et al., 2013). In brief, experiment 1 comprised 2 consecutive 14-d experimental periods separated by a 5 -d transition between diets. In the first period, cows were allowed to strip graze timothy (Phleum pratense) and meadow fescue (Festuca pratensis) swards for $7 \mathrm{~d}$ before being housed indoors and offered chopped grass harvested from the same pasture. Following a 5-d adaptation period, cows were offered hay also prepared from the same grass swards. For experiment 2, cows were assigned to 1 of 2 blocks according to stage of lactation and milk yield and allocated to treatments according to a replicated $3 \times 3$ Latin square with 14-d experimental periods. Experimental treatments comprised grass hay, grass silage prepared without additive (untreated, UTS), or grass silage prepared with formic acid-based additive (FAS; $6 \mathrm{~L} / \mathrm{t}$ of grass; AIV 2Plus; Kemira Ltd., Helsinki, Finland) prepared simultaneously from the same experimental pasture. For both experiments, forages were offered ad libitum in amounts to ensure $10 \%$ refusals and supplemented with the same standard concentrate distributed as equal meals at $0600,0800,1800$, and $2000 \mathrm{~h}$ at a rate of 7 or $9 \mathrm{~kg} / \mathrm{d}$, for experiments 1 and 2, respectively.

\section{Measurements, Sampling, and Chemical Analysis}

Milk yield was recorded daily throughout the experiment, but only measurements between d 12 to 14 of each period in both experiments were used for statistical analysis. Samples of milk were collected from each cow over 4 consecutive milkings, starting at $1645 \mathrm{~h}$ on d 12. Milk samples treated with preservative (bronopol; Valio Ltd., Helsinki, Finland) were stored at $4^{\circ} \mathrm{C}$, until analyzed for fat, CP, and lactose (MilkoScan 133B analyzer; Foss Electric A/S, Hillerød, Denmark). Unpreserved milk samples were also collected at the same time, stored immediately at $-20^{\circ} \mathrm{C}$, and composited according to milk yield until analyzed for FA composition. In addition, samples of unpreserved milk were collected at $1645 \mathrm{~h}$ on d 13 and $0700 \mathrm{~h}$ on d 14, stored at $4^{\circ} \mathrm{C}$, composited according to yield, and submitted for the determination of urea concentrations (Shingfield et al., 2002a).

Samples of blood were collected simultaneously from coccygeal vessels and caudal superficial epigastric veins 
into $3 \times 10-\mathrm{mL}$ collection tubes containing EDTA (Venoject; Terumo Europe Ltd., Leuven, Belgium) at 0600, 0900, and $1200 \mathrm{~h}$ on d 14 of each experimental period. Blood samples were collected 3 times daily to minimize the influence of diurnal variation in plasma lipid composition. Coccygeal vessels and superficial epigastric veins were used as convenient sites for the sampling of arterial blood and mammary gland venous blood, respectively (Cant et al., 1993). Once collected, tubes were placed on ice. Plasma was recovered by centrifugation at $3,000 \times g$ for $15 \mathrm{~min}$ at $4^{\circ} \mathrm{C}$, frozen immediately at $-20^{\circ} \mathrm{C}$, and composited across sampling times for each cow. Once plasma from the third blood sample had been recovered, composite samples were stored at $-80^{\circ} \mathrm{C}$ until analyzed for lipid composition. Plasma glucose and BHBA were analyzed using standard methods (Shingfield et al., 2002b). Plasma amino acid concentrations were determined following the precipitation of protein with $12 \%$ sulfosalicylic acid (1:2, vol/vol) using an autoanalyzer (Biochrom 20; Pharmacia Biotech, Cambridge, UK) equipped with 90 $\times$ 4.6-mm PEEK lithium prewash column and $250 \times$ $4.6 \mathrm{~mm}$ Bio PEEK lithium high-performance column (Pharmacia Biotech) in accordance with the procedures recommended by the manufacturer.

\section{Lipid Analysis}

Lipid in $3 \mathrm{~mL}$ of plasma was extracted in duplicate using a mixture of hexane and isopropanol (3:2, vol/ vol). Organic extracts were combined, evaporated to dryness at $45^{\circ} \mathrm{C}$ under nitrogen, and dissolved in 0.5 $\mathrm{mL}$ of chloroform. Phospholipid (PL), cholesterol ester (CE), triacylglycerol (TAG), and NEFA were separated by solid-phase extraction using Bond Elut $\mathrm{NH}_{2}$ aminopropyl-bonded silica cartridges (500 mg; Varian Inc., Lake Forest, CA) loaded on a Visiprep (Supelco Inc., Bellefonte, PA) vacuum filtering unit operated under atmospheric pressure. Plasma PL, CE, TAG, and NEFA were recovered by eluting columns with methanol, hexane, a mixture of $1 \%$ diethyl ether, and $10 \%$ methylene chloride in hexane ( $\mathrm{vol} / \mathrm{vol})$, or $2 \%$ acetic acid in diethyl ether (vol/vol), respectively (Kaluzny et al., 1985). Concentrations of PL, CE, TAG, and NEFA in plasma samples were determined using 1,2-diheptadecanoyl-sn-glycero-3-phosphatidylcholine (37-170011; Larodan Fine Chemicals AB, Malmö, Sweden), cholesteryl pentadecanoate (CH-814; Nu-Chek Prep Inc., Elysian, MN), tritridecanoin (T-135; Nu-Chek Prep Inc.), and tricosanoic acid (N-23A; Nu-Chek Prep Inc.) as internal standards, respectively. Internal standard solutions were prepared to contain $100 \mathrm{mg}$ of CE, TAG, or NEFA in $100 \mathrm{~mL}$ of hexane or $100 \mathrm{mg}$ of PL in $100 \mathrm{~mL}$ of chloroform with $1 \mathrm{~mL}$ of each added to plasma samples for quantitative determinations. Fatty acids in TAG and PL fractions were transesterified to FA methyl esters (FAME) by incubation with $2 \mathrm{~mL}$ of hexane and $40 \mu \mathrm{L}$ of fresh methylation reagent $(1.75$ $\mathrm{mL}$ methanol and $0.4 \mathrm{~mL}$ of Na-methoxide solution; Fluka reagent 71748 ) at $20^{\circ} \mathrm{C}$ for $5 \mathrm{~min}$. Methyl esters of NEFA and CE were prepared by incubation with 1.5 $\mathrm{mL}$ of $1 \%$ (vol/vol) sulfuric acid in methanol at $50^{\circ} \mathrm{C}$ for $30 \mathrm{~min}$ and $24 \mathrm{~h}$, respectively. Lipid in 1-mL milk samples was extracted 3 times with a mixture of ammonia, methanol, diethyl ether, and hexane (0.2:1:2.5:2.5, $\mathrm{vol} / \mathrm{vol} / \mathrm{vol}$, respectively) and converted to FAME using methanolic sodium methoxide as a catalyst (Halmemies-Beauchet-Filleau et al., 2011).

Samples of FAME were quantified using a gas chromatograph (model 6890; Hewlett-Packard, Wilmington, DE) equipped with a flame-ionization detector, automatic injector, split injection port, and a 100-m fused silica capillary column (0.25-mm i.d.) coated with a $0.2-\mu \mathrm{m}$ film of cyanopropyl polysiloxane (CP-SIL, Chromopack 7489; Chromopack, Middelburg, the Netherlands). The total FAME profile in a $2-\mu \mathrm{L}$ sample at a split ratio of 1:50 was determined using a temperature gradient program and hydrogen as a carrier gas operated at constant pressure $(137.9 \mathrm{kPa})$ at a flow rate of $0.5 \mathrm{~mL} / \mathrm{min}$. Isomers of $18: 1$ were further resolved in a separate analysis under isothermal conditions at $170^{\circ} \mathrm{C}$. Peaks were identified by comparison of retention times with authentic FAME standards and by GC-MS analysis of 4,4-dimethyloxoline derivatives prepared from FAME. Preparation of 4,4-dimethyloxazoline (DMOX) derivatives, parameters used for GC-MS analysis, and interpretation mass spectra were in accordance with earlier reports (Halmemies-Beauchet-Filleau et al., 2011). Relative retention time and order of elution was used to differentiate between diastereomers of 2,6,10,14-tetramethyl-15:0 (Ackman and Hansen, 1967) and 3,7,11,15-tetramethyl-16:0 (Schröder and Vetter, 2011). The distribution of CLA isomers in milk samples was determined using an HPLC system (model 1090; Hewlett-Packard) equipped with 4 silver-impregnated silica columns (ChromSpher 5 Lipids, $250 \times 4.6 \mathrm{~mm}$, $5-\mu \mathrm{m}$ particle size; Varian Ltd., Walton-on-Thames, UK) coupled in series. Methyl esters of CLA were separated under isothermal conditions at $22^{\circ} \mathrm{C}$ using $0.1 \%$ ( vol/vol) acetonitrile in heptane at a flow rate of $1 \mathrm{~mL} /$ min and monitoring column effluent at 233 and $210 \mathrm{~nm}$ (Halmemies-Beauchet-Filleau et al., 2011).

Plasma and milk FA composition were expressed as a weight percentage of total FA using theoretical relative response factors (Halmemies-Beauchet-Filleau et al., 2011) to account for the carbon deficiency in the flame ionization detector response for FAME containing 4- to 10-carbon atoms. Concentrations of specific 
conjugated isomers were calculated based on proportionate peak area responses determined by HPLC and the sum of trans-7,cis-9 CLA, trans-8,cis-10 CLA, and cis-9,trans-11 CLA weight percentage determined by GC.

\section{Calculations}

Metabolizable energy content of experimental diets was calculated from the concentration of digestible nutrients $[0.016 \times$ digestible $\mathrm{OM}$ in DM $(\mathrm{g} / \mathrm{kg})$; Ministry of Agriculture, Fisheries and Food, 1975] determined by total fecal collection (Halmemies-Beauchet-Filleau et al., 2013). The energy requirement (MJ/d) for maintenance and milk production was calculated as $[\mathrm{BW}$ $\left(\mathrm{kg}^{0.75}\right) \times 0.515+$ ECM yield $(\mathrm{kg} / \mathrm{d}) \times 5.15 ;$ MTT Agrifood Research Finland, 2010].

Extraction (\%) of lipid and metabolites by the mammary gland from arterial plasma was calculated as (arterial-venous concentration)/arterial concentration $\times 100$. Mammary plasma flow was calculated according to the Fick principle based on the stoichiometric transfer of mammary Phe and Tyr uptake into milk (Cant et al., 1993). Secretion of Phe and Tyr in milk was estimated from the difference in milk $\mathrm{CP}$ and urea output, known amino acid content of milk true protein, and assuming a $3.5 \%$ contribution originating from the transfer from blood-borne albumin and immunoglobulins (Cant et al., 1993), but excluding free Phe and Tyr concentrations:

$$
\begin{gathered}
\text { Mammary plasma flow }=(\text { milk Phe }+ \text { Tyr }) \\
\times 0.965 / \text { (arteriovenous difference of Phe }+ \text { Tyr }) .
\end{gathered}
$$

Mammary uptake (mmol/d) of individual FA was calculated as the product of arteriovenous differences in plasma TAG $(\mathrm{mmol} / \mathrm{L}) \times$ mammary plasma flow $(\mathrm{L} / \mathrm{d})$. Owing to the positive extraction of NEFA across the mammary glands during zero grazing, the contribution of both TAG and NEFA was included in the calculation of total mammary FA uptake for cows fed diets based on fresh grass in experiment 1. Mammary uptake $(\mathrm{mmol} / \mathrm{d})$ of metabolites was calculated as arteriovenous differences in plasma $(\mathrm{mmol} / \mathrm{L}) \times$ mammary plasma flow $(\mathrm{L} / \mathrm{d})$.

Fatty acid balance across the mammary glands was calculated as secretion in milk $(\mathrm{mmol} / \mathrm{d})$ - mammary gland uptake $(\mathrm{mmol} / \mathrm{d})$, assuming negligible oxidation of $\geq 16$-carbon FA (Annison et al., 1968) and that FA synthesized de novo were not utilized for processes other than desaturation or milk TAG synthesis. Relative proportions of SFA in milk fat synthesized de novo (\%) was calculated as [secretion in milk $(\mathrm{mmol} / \mathrm{d})$
- mammary uptake $(\mathrm{mmol} / \mathrm{d})] /[$ secretion in milk $(\mathrm{mmol} / \mathrm{d})] \times 100$. Desaturation of FA $(\%)$ in the mammary glands was calculated as [mammary balance of product $(\mathrm{mmol} / \mathrm{d})] /[$ mammary availability of substrate $(\mathrm{mmol} / \mathrm{d})] \times 100$, taking into account that 10:0 is synthesized exclusively de novo, 18-and-longer-carbon FA originated from plasma, whereas 12:0, 14:0, and 16:0 are derived from both sources.

\section{Statistical Analysis}

Treatment means in experiment 1 were evaluated by a paired $t$-test (SAS version 9.2; SAS Institute Inc., Cary, NC). In all cases, a 95\% confidence interval was used as the default for the hypothesis test, whereas assumptions of normality were validated using the univariate procedure. Differences between treatment means were considered to reflect the effect of forage conservation by drying.

For experiment 2, data were analyzed by ANOVA for a replicated $3 \times 3$ Latin square with 5 cows to evaluate 3 treatments over 3 experimental periods, with a model that included the fixed effects of treatment and period and random effects of block and cow within block using PROC MIXED of SAS. Sums of squares were further separated into single-degree-of-freedom contrasts to test for the significance of forage conservation by drying versus ensiling (method = hay vs. UTS and FAS) and extent of silage fermentation (UTS vs. FAS). Least squares means are reported, with treatment effects declared significant at $P \leq 0.05$. Differences between treatments with $P$-values between 0.05 and 0.10 were considered a trend toward significance. Relationships between FA flows at the omasum (Halmemies-BeauchetFilleau et al., 2013), arterial plasma lipid composition, and secretion of FA in milk were evaluated by linear regression analysis using PROC REG of SAS.

\section{RESULTS}

\section{Milk Production}

Fresh grass in the diet had no effect $(P>0.10)$ on milk yield, or milk fat or protein content, but increased $(P<0.03)$ milk fat secretion compared with hay (Table 1). Relative to hay, diets based on silage resulted in higher $(P<0.04)$ milk and milk fat yield, but had no effect $(P>0.10)$ on milk constituent concentrations (Table 1). Compared with UTS, FAS increased $(P<$ 0.04 ) the yield of milk fat and milk protein (Table 1 ). Cows were in positive energy balance across all treatments. However, calculated energy balance tended $(P=$ 0.08 ) to be lower in cows offered fresh grass compared with hay (Table 1). 
Table 1. Effect of fresh grass or conserved forages on energy intake and milk production in lactating cows

\begin{tabular}{|c|c|c|c|c|c|c|c|c|c|c|}
\hline \multirow[b]{2}{*}{ Item } & \multicolumn{4}{|c|}{ Experiment 1} & \multicolumn{6}{|c|}{ Experiment 2} \\
\hline & Grass & Hay & $\mathrm{SEM}^{1}$ & $P$-value & Hay & $\mathrm{UTS}^{2}$ & FAS $^{3}$ & $\mathrm{SEM}^{4}$ & Method & Extent \\
\hline ME intake, MJ/d & 199 & 209 & 10.2 & 0.36 & 221 & 229 & 247 & 11.9 & 0.012 & 0.017 \\
\hline ME balance, MJ/d & 0.53 & 20.7 & 8.48 & 0.08 & 10.5 & 11.8 & 16.1 & 5.57 & 0.53 & 0.50 \\
\hline \multicolumn{11}{|l|}{ Yield, kg/d } \\
\hline Fat & 1.10 & 1.01 & 0.025 & 0.022 & 1.13 & 1.20 & 1.32 & 0.090 & $<0.001$ & $<0.001$ \\
\hline Protein & 0.89 & 0.85 & 0.049 & 0.46 & 0.91 & 0.90 & 1.01 & 0.059 & 0.19 & 0.032 \\
\hline Lactose & 1.11 & 1.03 & 0.053 & 0.22 & 1.44 & 1.52 & 1.58 & 0.102 & 0.13 & 0.45 \\
\hline \multicolumn{11}{|c|}{ Concentration in milk, \% } \\
\hline Fat & 4.49 & 4.38 & 0.240 & 0.67 & 3.83 & 3.88 & 4.04 & 0.119 & 0.44 & 0.39 \\
\hline Protein & 3.62 & 3.68 & 0.050 & 0.25 & 3.12 & 2.97 & 3.13 & 0.194 & 0.53 & 0.26 \\
\hline Lactose & 4.47 & 4.40 & 0.045 & 0.18 & 4.91 & 4.87 & 4.84 & 0.045 & 0.31 & 0.67 \\
\hline
\end{tabular}

${ }^{1}$ Standard error of the mean for $\mathrm{n}=10$ measurements; error degree of freedom $=4$.

${ }^{2}$ Untreated silage.

${ }^{3}$ Silage ensiled using a formic acid-based additive.

${ }^{4}$ Standard error of the mean for $\mathrm{n}=15$ measurements; error degree of freedom $=6$.

${ }^{5}$ Significance of effect due to forage conservation method (drying vs. ensiling; method) or extent of silage fermentation (extensively vs. restrictively fermented silage; extent).

\section{Concentration and Extraction of Plasma Lipids and Metabolites}

Circulating PL and CE represented the major lipid fractions in arterial and venous blood, whereas concentrations of TAG and NEFA were several-fold lower (Table 2). On all diets, TAG in arterial blood was the major source of preformed FA for milk fat synthesis (Table 2). With the exception of cows fed fresh grass, arteriovenous differences indicated a net efflux of NEFA from the mammary gland (Table 2). In most cases, mammary extraction of arterial CE and PL was negligible, whereas forage conservation had often significant, but quantitatively small effects (Table 2). Associations between the flow of specific FA at the omasum with their concentration in arterial blood, uptake across the mammary glands, and secretion in milk are presented in Supplemental Table S4 (available online at http:// www.journalofdairyscience.org/).

Treatments had no effect $(P>0.10)$ on glucose and urea levels in arterial or venous plasma, or on the rate of mammary extraction of BHBA, glucose, and urea across the mammary glands (Table 2). Mammary uptake of BHBA and urea was unaffected by treatment, whereas the uptake of glucose tended to be higher $(P \leq$ $0.07)$ for fresh grass compared with hay and for silages relative to hay (Table 2).

Fresh Grass Versus Grass Hay. Fresh grass resulted in higher $(P<0.03)$ PL and NEFA concentrations in arterial blood, elevated PL and $\mathrm{CE}$ in venous blood, and tended $(P=0.08)$ to increase TAG in arte- rial blood compared with hay (Table 2). Plasma BHBA concentrations did not differ $(P>0.10)$ between cows offered fresh grass or grass hay (Table 2).

Grass Hay Versus Grass Silage. Relative to hay, diets based on grass silage increased $(P<0.04)$ PL and TAG concentrations in arterial blood, TAG and NEFA in venous blood, and BHBA in arterial and venous blood (Table 2).

Extent of Silage Fermentation. Compared with UTS, FAS elevated $(P<0.05)$ NEFA in arterial and venous blood, and increased $(P<0.05)$ arterial $\mathrm{CE}$ and BHBA concentrations (Table 2).

\section{FA Composition of Plasma Lipids}

Circulating PL in arterial blood were relatively abundant in 3,7,11,15-tetramethyl-16:0 (Supplemental Figure S1, available online at http://www.journalof dairyscience.org/), 16:0, 18:0, cis-9 18:1, and 18:2n-6, 20- and 22-carbon PUFA (Table 3). Cholesterol esters were rich in 18:2n-6, with 18:3n-3 as a major component (Table 4). In contrast, 16:0 and 18:0 predominated in TAG (Table 5), whereas the FA composition of NEFA resembled that of TAG (Table 6). Triacylglycerols were the main repository for the transport of 2,6,10,14-tetramethyl-15:0 in arterial and venous blood (Tables 3 to 6$)$.

Fresh Grass Versus Grass Hay. Relative concentrations of 18:3n-3 in CE and TAG fractions in arterial blood were higher $(P<0.02)$ in cows fed fresh grass 
Table 2. Effect of fresh grass or conserved forages on the concentration and mammary extraction of plasma lipid fractions and metabolites in lactating cows

\begin{tabular}{|c|c|c|c|c|c|c|c|c|c|c|}
\hline Item $^{1}$ & \multicolumn{4}{|c|}{ Experiment 1} & \multicolumn{6}{|c|}{ Experiment 2} \\
\hline \multicolumn{11}{|c|}{ Arterial concentration, $\mathrm{mg} / \mathrm{dL}$} \\
\hline PL & 104 & 91.1 & 3.00 & 0.013 & 122 & 131 & 145 & 9.5 & 0.023 & 0.06 \\
\hline $\mathrm{CE}$ & 92.7 & 83.9 & 11.10 & 0.48 & 124 & 125 & 137 & 7.5 & 0.11 & 0.041 \\
\hline BHBA, mmol/L & 0.72 & 0.73 & 0.054 & 0.89 & 0.74 & 0.88 & 1.06 & 0.087 & 0.007 & 0.036 \\
\hline Glucose, $\mathrm{mmol} / \mathrm{L}$ & 3.85 & 3.71 & 0.128 & 0.33 & 3.64 & 3.67 & 3.63 & 0.114 & 0.89 & 0.72 \\
\hline Urea, $\mathrm{mmol} / \mathrm{L}$ & 3.84 & 3.84 & 0.311 & 1.00 & 4.59 & 4.56 & 4.94 & 0.633 & 0.81 & 0.61 \\
\hline \multicolumn{11}{|c|}{ Venous concentration, $\mathrm{mg} / \mathrm{dL}$} \\
\hline PL & 104 & 88.3 & 1.77 & $<0.001$ & 129 & 132 & 143 & 9.2 & 0.16 & 0.15 \\
\hline $\mathrm{CE}$ & 98.1 & 85.2 & 3.81 & 0.028 & 128 & 130 & 137 & 8.8 & 0.20 & 0.18 \\
\hline TAG & 3.99 & 4.03 & 0.327 & 0.89 & 2.28 & 3.33 & 3.54 & 0.341 & 0.033 & 0.69 \\
\hline PL & -0.3 & 3.1 & 2.50 & 0.25 & -5.1 & -0.7 & 1.6 & 2.43 & 0.041 & 0.40 \\
\hline $\mathrm{CE}$ & -5.9 & -5.2 & 12.32 & 0.96 & -3.6 & -4.3 & 0.9 & 1.71 & 0.32 & 0.043 \\
\hline TAG & 53.2 & 44.2 & 4.98 & 0.15 & 56.8 & 48.3 & 47.9 & 4.58 & 0.18 & 0.95 \\
\hline NEFA & 17.1 & -9.9 & 9.84 & 0.06 & -13.9 & -18.0 & -9.8 & 7.58 & 1.00 & 0.46 \\
\hline $\mathrm{TAG}+\mathrm{NEFA}$ & 35.4 & 30.0 & 2.96 & 0.14 & 31.5 & 25.3 & 27.2 & 2.04 & 0.06 & 0.49 \\
\hline BHBA & 36.5 & 33.5 & 5.30 & 0.60 & 38.7 & 32.1 & 32.1 & 3.38 & 0.17 & 1.00 \\
\hline Glucose & 18.3 & 17.2 & 0.96 & 0.35 & 18.3 & 19.4 & 21.5 & 2.18 & 0.37 & 0.44 \\
\hline Urea & -1.8 & 1.8 & 5.52 & 0.56 & -5.1 & -3.0 & -3.7 & 3.33 & 0.69 & 0.90 \\
\hline \multicolumn{11}{|c|}{ Mammary uptake, mol/d } \\
\hline BHBA & 3.08 & 2.83 & 0.217 & 0.31 & 3.60 & 4.18 & 5.03 & 0.579 & 0.20 & 0.34 \\
\hline Glucose & 8.09 & 7.18 & 0.329 & 0.06 & 8.57 & 9.65 & 11.7 & 1.133 & 0.07 & 0.11 \\
\hline Urea & -1.65 & 1.06 & 2.328 & 0.31 & -3.44 & -2.12 & -2.69 & 2.026 & 0.70 & 0.86 \\
\hline
\end{tabular}

${ }^{1} \mathrm{PL}=$ phospholipid; $\mathrm{CE}=$ cholesterol ester; $\mathrm{TAG}=$ triacylglycerol.

${ }^{2}$ Standard error of the mean for $\mathrm{n}=10$ measurements; error degree of freedom $=4$.

${ }^{3}$ Untreated silage.

${ }^{4}$ Silage ensiled using a formic acid-based additive.

${ }^{5}$ Standard error of the mean for $\mathrm{n}=15$ measurements; error degree of freedom $=6$.

${ }^{6}$ Significance of effect due to forage conservation method (drying vs. ensiling; method) or extent of silage fermentation (extensively vs. restrictively fermented silage; extent).

compared with hay (Tables 4 and 5). Furthermore, fresh grass in the diet increased $(P<0.01)$ the abundance of 18:2n-6 in arterial TAG (Table 5) compared with hay. Relative to hay, fresh grass had no effect $(P>0.05)$ on 18:0 concentrations of arterial lipid fractions (Tables 3 to 6$)$, but resulted in a marked increase $(P<0.04)$ in the relative proportions of 16:0 in circulating NEFA (Table 6), and cis-9 18:1 of PL and NEFA fractions (Tables 3 and 6). Furthermore, incorporation of trans-11 18:1 and cis-9,trans-11 CLA in plasma PL tended $(P \leq 0.07)$ to be higher for fresh grass compared with hay (Table 3 ), whereas enrichment in arterial TAG and NEFA did not differ $(P>0.10$; Tables 5 and 6$)$.

Grass Hay Versus Grass Silage. Differences in the composition of major FA in plasma lipids of cows fed grass silages or hay were relatively minor (Tables 3 to 6$)$. Relative to hay, silage increased $(P<0.02)$ 18:3n-3 concentrations of PL and CE in arterial blood (Tables 3 and 4). Even though hay decreased $(P<$ 0.01 ) the relative proportions of $18: 2 \mathrm{n}-6$ in arterial $\mathrm{PL}$ and CE compared with silages, absolute concentrations of 18:2n-6 transported by both lipid fractions in arterial blood were similar across diets. Compared with hay, feeding silage resulted in higher $(P<0.02)$ concentrations of 3S,7R,11R,15-tetramethyl-16:0 in PL, TAG, and NEFA fractions in arterial blood and enrichment of 3R,7R,11R,15-tetramethyl-16:0 in arterial PL (Tables $3,5$, and 6$)$.

Extent of Silage Fermentation. Restricting fermentation in silo had no effect $(P>0.10)$ on the enrichment of 16:0, 18:0, cis-9,trans-11 CLA, 18:2n-6, or 18:3n-3 in lipids circulating in arterial blood, other than a trend toward decreasing $(P=0.08) 18: 3 \mathrm{n}-3$ concentrations in PL and $(P=0.09)$ increasing the 
Table 3. Effect of fresh grass or conserved forages on the FA composition of phospholipids in arterial blood of lactating cows

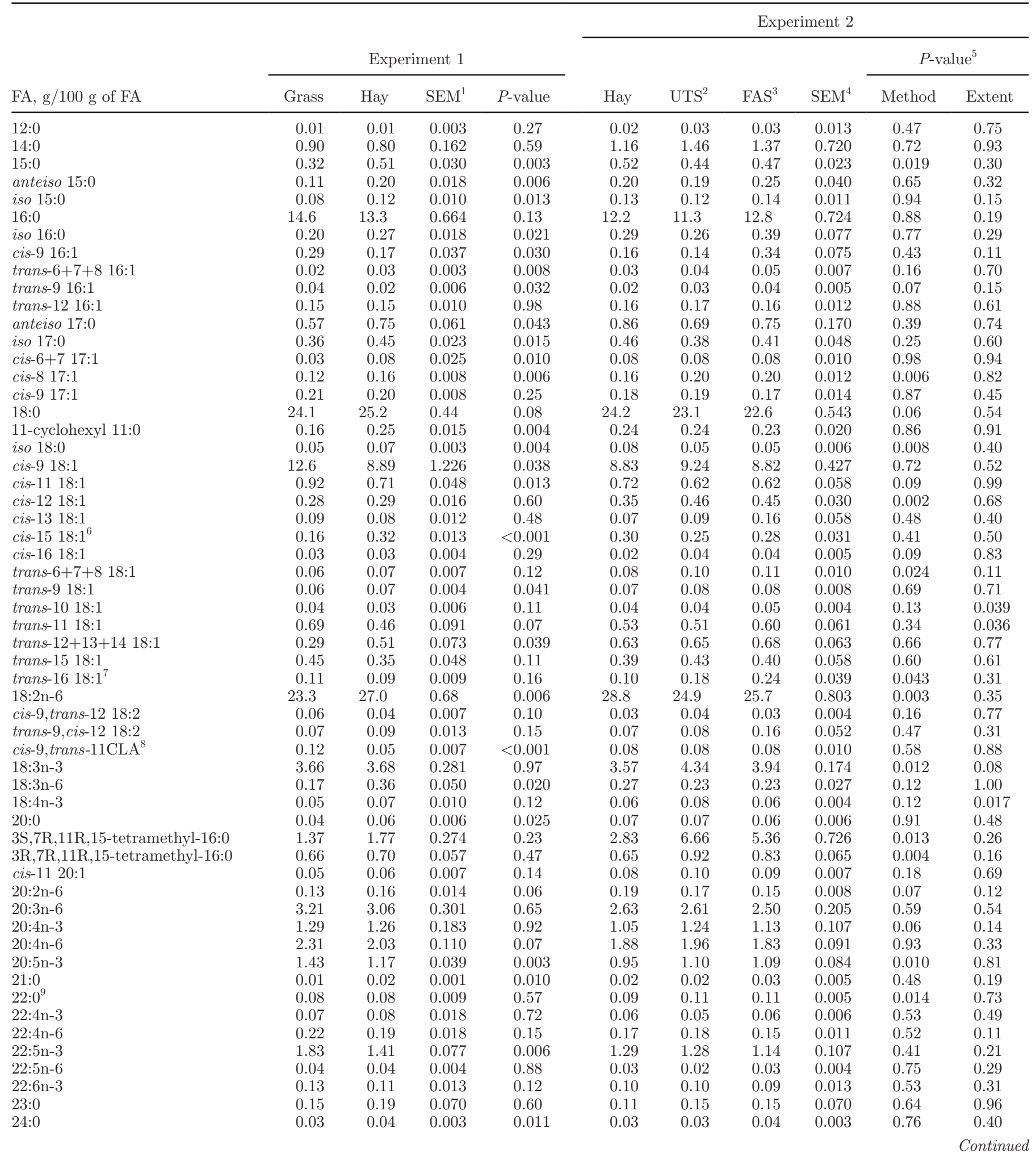


Table 3 (Continued). Effect of fresh grass or conserved forages on the FA composition of phospholipids in arterial blood of lactating cows

\begin{tabular}{|c|c|c|c|c|c|c|c|c|c|c|}
\hline \multirow[b]{3}{*}{$\mathrm{FA}, \mathrm{g} / 100 \mathrm{~g}$ of $\mathrm{FA}$} & \multirow{2}{*}{\multicolumn{4}{|c|}{ Experiment 1}} & \multicolumn{6}{|c|}{ Experiment 2} \\
\hline & & & & & \multirow[b]{2}{*}{ Hay } & \multirow[b]{2}{*}{$\mathrm{UTS}^{2}$} & \multirow[b]{2}{*}{ FAS $^{3}$} & \multirow[b]{2}{*}{$\mathrm{SEM}^{4}$} & \multicolumn{2}{|c|}{$P$-value ${ }^{5}$} \\
\hline & Grass & Hay & $\mathrm{SEM}^{1}$ & $P$-value & & & & & Method & Extent \\
\hline $26: 0$ & 0.01 & 0.01 & 0.002 & 0.59 & 0.01 & 0.02 & 0.03 & 0.010 & 0.38 & 0.46 \\
\hline 28:0 & 0.02 & 0.01 & 0.006 & 0.11 & 0.02 & 0.02 & 0.02 & 0.002 & 0.13 & 0.83 \\
\hline$\Sigma$ Unidentified & 1.28 & 1.61 & 0.119 & 0.06 & 1.61 & 1.73 & 1.80 & 0.114 & 0.30 & 0.65 \\
\hline \multicolumn{11}{|c|}{${ }^{2}$ Untreated silage. } \\
\hline \multicolumn{11}{|c|}{${ }^{3}$ Silage ensiled using a formic acid-based additive. } \\
\hline \multicolumn{11}{|c|}{${ }^{4}$ Standard error of the mean for $\mathrm{n}=15$ measurements; error degree of freedom $=6$. } \\
\hline \multicolumn{11}{|c|}{$\begin{array}{l}{ }^{5} \text { Significance of effect due to forage conservation method (drying vs. ensiling; method) or extent of silage fermentation (extensively vs. restric } \\
\text { tively fermented silage; extent). }\end{array}$} \\
\hline \multicolumn{11}{|c|}{${ }^{6}$ Co-elutes with 19:0. } \\
\hline \multicolumn{11}{|c|}{${ }^{7}$ Co-elutes with cis-14 18:1. } \\
\hline
\end{tabular}

proportion of 16:0 in NEFA. However, compared with UTS, FAS increased $(P<0.04)$ trans-11 18:1 abundance in PL and NEFA fractions (Tables 3 and 6) and the proportions of cis-9 18:1 in NEFA of arterial blood (Table 6).

\section{Mammary FA Metabolism}

The uptake of individual FA from arterial blood and the overall balance of FA across the mammary glands are shown in Table 7 . On average, 16:0, 18:0, and cis-9 18:1 accounted for 19 to 23,34 to 47 , and 7 to $22 \%$ of total FA uptake across the mammary glands, respectively. For diets based on hay or silages, 16:0 was the major FA synthesized de novo, whereas synthesis of 4:0, 14:0, and 16:0 in the mammary glands were of a similar magnitude on fresh grass. Across all treatments, synthesis de novo accounted for, on average 98, 95, and $74 \%$ of mammary 12:0, 14:0, and 16:0 secretion, respectively (Table 8). Furthermore, on average, 54 and $24 \%$ of 18:0 and trans-11 18:1 extracted from arterial plasma were desaturated in the mammary glands, respectively (Table 8). Conversion of 18:0 to cis-9 18:1 accounted for, on average, $71 \%$ of total FA desaturation in the mammary glands, with the formation of cis-9 14:1 and cis-9 16:1 accounting for 10 and $11 \%$, respectively, whereas that associated with the synthesis of cis-9 10:1, cis-9 12:1, cis-9,trans-11 CLA, and cis-9 20:1 were marginal $(4,<0.1,2$, and $1 \%$, respectively). For fresh grass, $53 \%$ of cis-9 18:1 secreted in milk originated from the desaturation of 18:0 in the mammary glands, whereas the contribution of stearoyl CoA desaturase to cis-9 18:1 output in milk was higher (ca. $76 \%$ ) for hay and grass silages. Overall, ca. $78 \%$ of cis-9,trans-11 CLA secreted in milk originated from the desaturation of trans-11 18:1 in the mammary glands, with no evidence of differences among treatments (data not presented).

Fresh Grass Versus Grass Hay. Mammary FA uptake was ca. $70 \%$ higher for fresh grass compared with hay. Compared with hay, fresh grass resulted in higher $(P<0.01)$ uptakes of trans-11 18:1 and 18:3n-3 across the mammary glands, and numerical $(P>0.10)$ increases in mammary uptake of cis-9,trans-11 CLA and 18:2n-6 (Table 7). Zero grazing was also associated with greater $(P<0.03)$ uptakes of $16: 0,18: 0$, and cis-9 18:1 across the mammary glands compared with hay. Furthermore, mammary uptake of 16:0 + cis-9 16:1, 18:0 + cis-9 18:1, and total FA for fresh grass exceeded the corresponding flows at the omasum by 146, 70, and 199 g/d, respectively (Supplemental Figure S2, available online at http://www.journalofdairyscience.org/).

Mammary synthesis of 16:0 de novo was markedly lower $(P<0.01)$, and that of 12:0 tended $(P=0.08)$ to be lower in cows fed fresh grass relative to hay (Table 7). Compared with hay, fresh grass decreased $(P \leq$ $0.04)$ the desaturation of 14:0 and 18:0 in the mammary glands, but had no effect $(P>0.10)$ on the conversion of trans-11 18:1 to cis-9,trans-11 CLA (Table 8). However, the amount of cis-9, trans-11 CLA synthesized in the mammary glands was higher $(P=0.03)$ for cows during zero grazing compared with hay (Table 7).

Grass Hay Versus Grass Silage. Feeding extensively or restrictively fermented silages had no effect $(P>0.10)$ on mammary cis-9 18:1, 18:2n-6, or 18:3n-3 uptake compared with hay, whereas grass silage diets tended $(P \leq 0.10)$ to increase the uptake of 18:0 and trans-11 18:1 across the mammary glands (Table 7). Relative to hay, silages increased $(P<0.02)$ the syn- 
Table 4. Effect of fresh grass or conserved forages on the FA composition of cholesterol esters in arterial blood of lactating cows

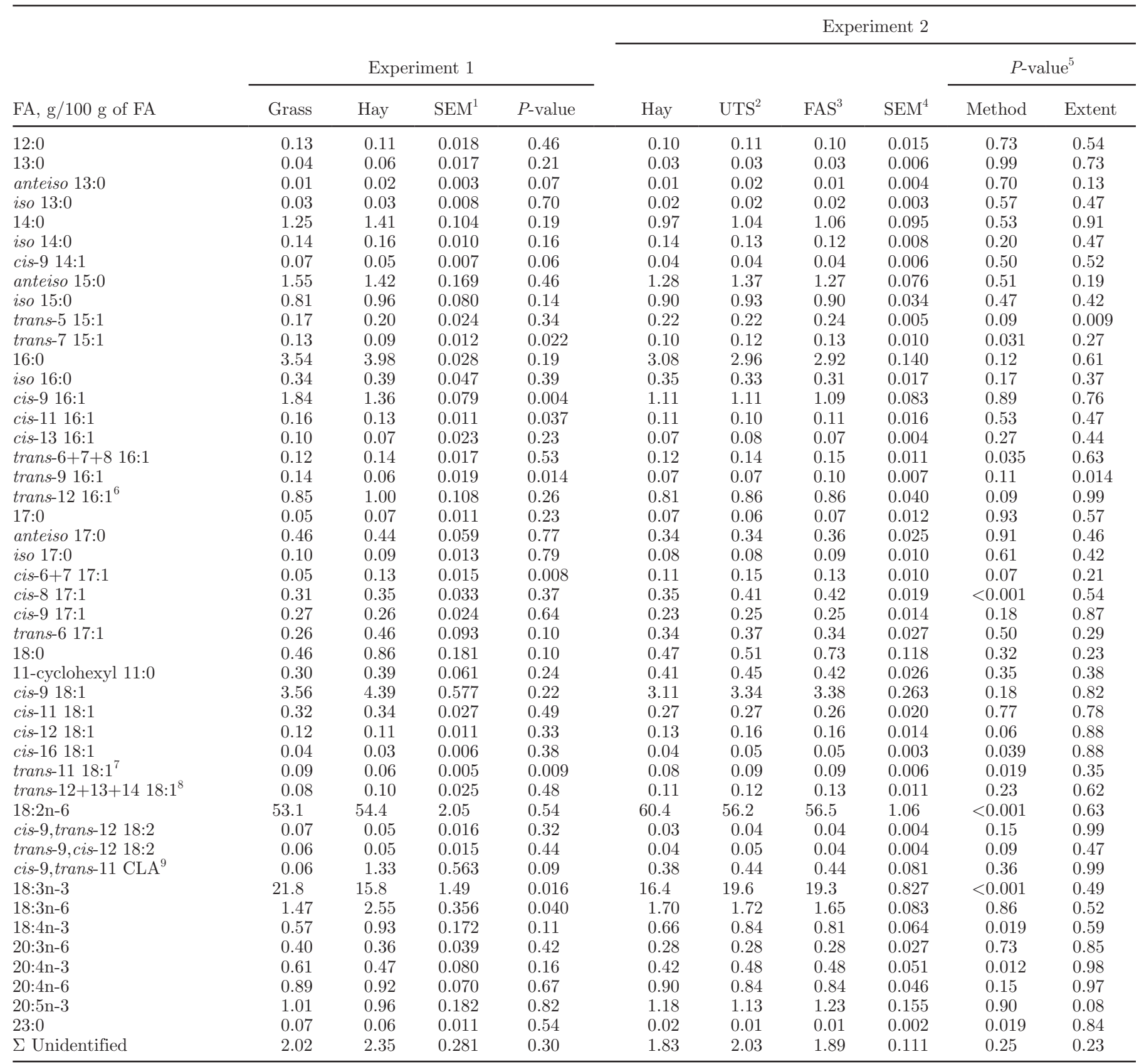

${ }^{1}$ Standard error of the mean for $\mathrm{n}=10$ measurements; error degree of freedom $=4$.

${ }^{2}$ Untreated silage.

${ }^{3}$ Silage ensiled using a formic acid-based additive.

${ }^{4}$ Standard error of the mean for $\mathrm{n}=15$ measurements; error degree of freedom $=6$.

${ }^{5}$ Significance of effect due to forage conservation method (drying vs. ensiling; method) or extent of silage fermentation (extensively vs. restrictively fermented silage; extent).

${ }^{6}$ Co-elutes with cis-6 16:1.

${ }^{7}$ Co-elutes with cis-5 18:1.

${ }^{8}$ Co-elutes with cis-6+7+8 18:1.

${ }^{9} \mathrm{CLA}=$ conjugated linoleic acid. 
Table 5. Effect of fresh grass or conserved forages on the FA composition of triacylglycerols in arterial blood of lactating cows

\begin{tabular}{|c|c|c|c|c|c|c|c|c|c|c|}
\hline \multirow[b]{2}{*}{$\mathrm{FA}, \mathrm{g} / 100 \mathrm{~g}$ of $\mathrm{FA}$} & \multicolumn{4}{|c|}{ Experiment 1} & \multicolumn{6}{|c|}{ Experiment 2} \\
\hline & Grass & Hay & $\mathrm{SEM}^{1}$ & $P$-value & Hay & $\mathrm{UTS}^{2}$ & $\mathrm{FAS}^{3}$ & $\mathrm{SEM}^{4}$ & Method & Extent \\
\hline $12: 0$ & 0.21 & 0.31 & 0.011 & $<0.001$ & 0.33 & 0.35 & 0.25 & 0.047 & 0.67 & 0.20 \\
\hline 14:0 & 1.54 & 2.16 & 0.069 & $<0.001$ & 2.00 & 1.75 & 2.06 & 0.127 & 0.57 & 0.14 \\
\hline iso $14: 0$ & 0.20 & 0.44 & 0.036 & 0.003 & 0.39 & 0.27 & 0.28 & 0.028 & 0.020 & 0.73 \\
\hline anteiso $15: 0$ & 1.01 & 1.73 & 0.082 & $<0.001$ & 1.65 & 1.32 & 1.33 & 0.067 & 0.007 & 0.92 \\
\hline iso $15: 0$ & 0.70 & 1.40 & 0.132 & 0.006 & 1.22 & 1.13 & 1.10 & 0.164 & 0.55 & 0.88 \\
\hline $16: 0$ & 16.0 & 18.6 & 0.85 & 0.039 & 18.4 & 17.9 & 18.2 & 0.543 & 0.59 & 0.74 \\
\hline iso $16: 0$ & 0.56 & 0.76 & 0.083 & 0.07 & 0.67 & 0.53 & 0.49 & 0.042 & 0.002 & 0.31 \\
\hline cis-9 16:1 & 0.81 & 0.57 & 0.168 & 0.23 & 0.32 & 0.21 & 0.31 & 0.061 & 0.45 & 0.31 \\
\hline trans-6-8 $16: 1$ & 0.19 & 0.23 & 0.033 & 0.30 & 0.15 & 0.14 & 0.17 & 0.008 & 0.71 & 0.039 \\
\hline trans-9 16:1 & 0.14 & 0.08 & 0.034 & 0.15 & 0.11 & 0.14 & 0.15 & 0.033 & 0.36 & 0.88 \\
\hline cis-9 17:1 & 0.15 & 0.12 & 0.024 & 0.33 & 0.12 & 0.11 & 0.10 & 0.023 & 0.56 & 0.69 \\
\hline 18:0 & 25.9 & 32.3 & 2.79 & 0.09 & 35.5 & 36.5 & 36.7 & 1.73 & 0.63 & 0.94 \\
\hline 11-cyclohexyl 11:0 & 0.24 & 0.30 & 0.072 & 0.40 & 0.33 & 0.31 & 0.30 & 0.027 & 0.29 & 0.93 \\
\hline cis-9 18:1 & 7.87 & 6.69 & 1.318 & 0.42 & 6.59 & 6.57 & 6.52 & 0.583 & 0.96 & 0.95 \\
\hline cis-11 18:1 & 0.74 & 0.76 & 0.134 & 0.90 & 0.94 & 0.72 & 0.74 & 0.074 & 0.009 & 0.77 \\
\hline cis-12 18:1 & 0.11 & 0.14 & 0.035 & 0.44 & 0.23 & 0.26 & 0.24 & 0.023 & 0.58 & 0.65 \\
\hline cis-13 18:1 & 0.60 & 0.78 & 0.216 & 0.45 & 0.37 & 0.67 & 0.43 & 0.198 & 0.42 & 0.35 \\
\hline cis-15 $18: 1^{6}$ & 0.23 & 0.48 & 0.037 & 0.003 & 0.51 & 0.42 & 0.60 & 0.080 & 0.95 & 0.17 \\
\hline trans $-6+7+8 \quad 18: 1$ & 0.13 & 0.16 & 0.012 & 0.07 & 0.24 & 0.21 & 0.27 & 0.029 & 1.00 & 0.22 \\
\hline trans-9 18:1 & 0.10 & 0.11 & 0.016 & 0.39 & 0.14 & 0.15 & 0.16 & 0.018 & 0.40 & 0.68 \\
\hline trans-10 18:1 & 0.16 & 0.18 & 0.026 & 0.47 & 0.26 & 0.23 & 0.31 & 0.040 & 0.81 & 0.17 \\
\hline trans-11 18:1 & 1.61 & 1.61 & 0.169 & 0.99 & 1.97 & 1.87 & 2.13 & 0.231 & 0.86 & 0.25 \\
\hline trans $-12+13+14$ 18:1 & 0.37 & 0.78 & 0.094 & 0.013 & 0.80 & 0.88 & 0.87 & 0.056 & 0.31 & 0.89 \\
\hline trans-15 $18: 1$ & 0.36 & 0.32 & 0.025 & 0.17 & 0.38 & 0.63 & 0.57 & 0.044 & $<0.001$ & 0.07 \\
\hline cis-10 19:1 & 0.29 & 0.28 & 0.073 & 0.86 & 0.31 & 0.25 & 0.25 & 0.032 & 0.17 & 1.00 \\
\hline $20: 0$ & 0.37 & 0.62 & 0.064 & 0.020 & 0.61 & 0.49 & 0.51 & 0.024 & 0.010 & 0.53 \\
\hline 3S,7R,11R,15-tetramethyl-16:0 & 1.47 & 2.17 & 0.288 & 0.08 & 2.53 & 6.25 & 5.19 & 0.655 & 0.008 & 0.30 \\
\hline 3R,7R,11R,15-tetramethyl-16:0 & 1.62 & 1.66 & 0.274 & 0.90 & 1.41 & 1.27 & 1.49 & 0.211 & 0.91 & 0.46 \\
\hline $20: 3 n-6$ & 0.24 & 0.20 & 0.043 & 0.44 & 0.14 & 0.10 & 0.14 & 0.030 & 0.53 & 0.30 \\
\hline $20: 4 n-3$ & 0.41 & 0.24 & 0.065 & 0.07 & 0.18 & 0.15 & 0.17 & 0.042 & 0.61 & 0.69 \\
\hline $20: 4 n-6$ & 0.57 & 0.32 & 0.133 & 0.13 & 0.26 & 0.18 & 0.20 & 0.028 & 0.09 & 0.63 \\
\hline $20: 5 n-3$ & 1.46 & 0.66 & 0.251 & 0.034 & 0.29 & 0.19 & 0.20 & 0.049 & 0.16 & 0.93 \\
\hline $21: 0$ & 0.11 & 0.16 & 0.011 & 0.018 & 0.15 & 0.09 & 0.13 & 0.025 & 0.23 & 0.36 \\
\hline $22: 0$ & 0.23 & 0.42 & 0.044 & 0.012 & 0.36 & 0.27 & 0.30 & 0.024 & 0.006 & 0.18 \\
\hline $22: 5 n-3$ & 0.25 & 0.22 & 0.056 & 0.59 & 0.27 & 0.20 & 0.22 & 0.025 & 0.07 & 0.42 \\
\hline $23: 0$ & 0.20 & 0.33 & 0.013 & $<0.001$ & 0.27 & 0.22 & 0.24 & 0.043 & 0.47 & 0.76 \\
\hline cis-14 23:1 & 0.18 & 0.31 & 0.042 & 0.045 & 0.28 & 0.32 & 0.33 & 0.027 & 0.18 & 0.79 \\
\hline $24: 0$ & 0.35 & 0.50 & 0.065 & 0.09 & 0.34 & 0.30 & 0.30 & 0.043 & 0.26 & 0.99 \\
\hline cis-15 24:1 & 0.11 & 0.17 & 0.020 & 0.033 & 0.14 & 0.10 & 0.13 & 0.017 & 0.16 & 0.15 \\
\hline $25: 0$ & 0.06 & 0.08 & 0.014 & 0.22 & 0.07 & 0.07 & 0.06 & 0.021 & 0.80 & 0.75 \\
\hline $26: 0$ & 0.26 & 0.54 & 0.075 & 0.022 & 0.51 & 0.50 & 0.48 & 0.041 & 0.75 & 0.77 \\
\hline
\end{tabular}


Table 5 (Continued). Effect of fresh grass or conserved forages on the FA composition of triacylglycerols in arterial blood of lactating cows

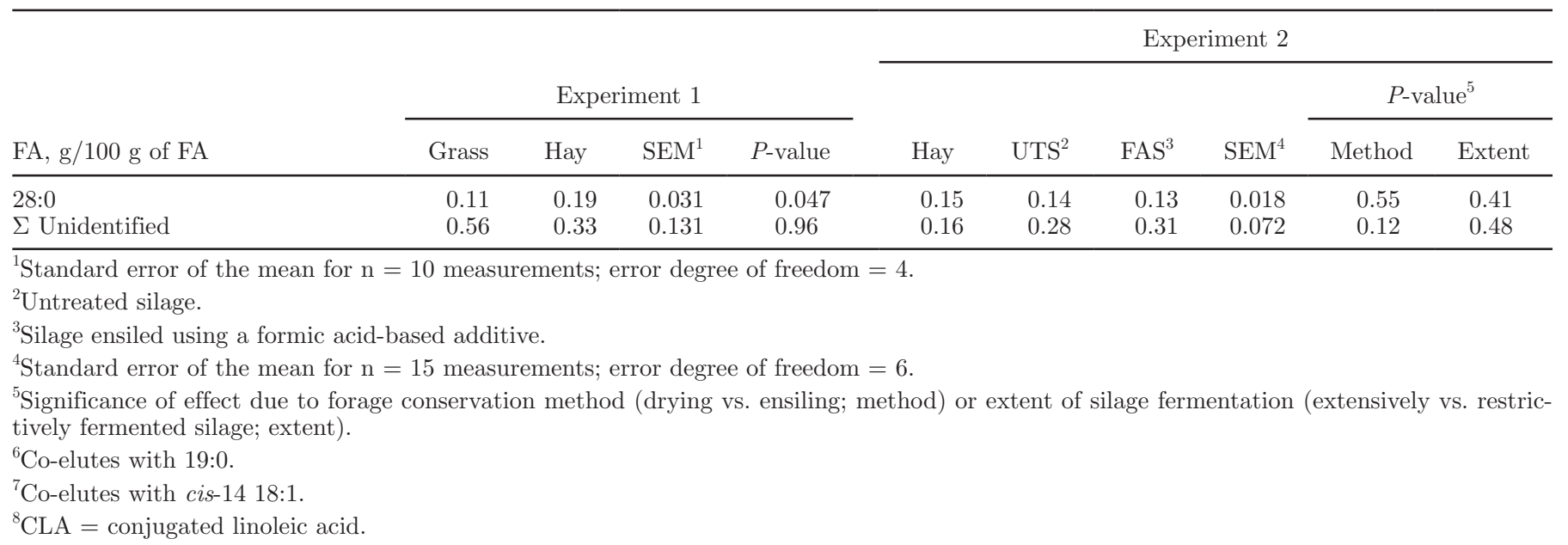

thesis of short- and medium-chain SFA (4-, 6-, 8-, and 14-carbon) de novo (Table 7). Furthermore, synthesis of 16:0 in the mammary glands tended to be higher $(P$ $=0.06$ ) in cows fed UTS and FAS than hay (Table 7). Compared with hay, silages had no effect $(P>0.10)$ on the extent of FA desaturation in the mammary glands, other than a tendency $(P=0.07)$ for lower conversion of 16:0 to cis-9 16:1 (Table 8).

Extent of Silage Fermentation. Restricting fermentation in silo had no effect $(P>0.10)$ on mammary FA uptake, other than increasing $(P<0.02)$ 18:3n-3 uptake from TAG in arterial blood (Table 7 ). Synthesis de novo of 4- to 10-even-carbon SFA, and 14:0 was also increased $(P<0.04)$ in the mammary glands of cows fed FAS compared with UTS (Table 7). However, the extent of fermentation in silo had no effect $(P>$ 0.10 ) on the extent of FA desaturation in the mammary glands (Table 8).

\section{Milk FA Composition and Secretion}

Fresh Grass Versus Grass Hay. Milk from fresh grass contained lower $(P \leq 0.05)$ 12:0, 14:0, 16:0, and total SFA concentrations compared with hay (mean responses of $-0.9,-2.0,-9.6$, and -10.4 percentage units, respectively; Table 9). Changes in milk fat composition were associated with a substantial decrease $(P$ $<0.01$ ) in the synthesis of 16:0 de novo in the mammary glands during zero grazing (Table 7). Overall, fresh grass resulted in higher $(P<0.05)$ milk fat 18:0, cis-18:1 $(\Delta 9-16)$, trans-18:1 $(\Delta 6-16)$, cis-9,trans-11 CLA, 18:2n-6, and 18:3n-3 concentrations compared with hay (Table 9; Supplemental Table S1, available online at http://www.journalofdairyscience.org/). Milk from fresh grass also contained higher $(P<0.05)$ concentrations of other PUFA, including trans-7, cis-9 CLA, $\Delta 11,13$ CLA, $\Delta 13,15$ CLA, $\Delta 9,12$ 18:2, $\Delta 11,15$
18:2, cis-9,trans-11,cis-15 18:3，20:3n-3，20:3n-6, and 22:5n-3 (Table 9; Supplemental Table S1) and lower $(P$ $\leq 0.02$ ) 18-carbon oxygenated FA content (Supplemental Table S3) relative to hay. However, fresh grass had variable effects $(P \leq 0.05)$ on the abundance of milk fat odd- and branched-chain FA compared with hay (Supplemental Table S3).

Relative to hay, fresh grass lowered $(P<0.05)$ 16:0 secretion and increased $(P<0.05)$ the output of 18:0, cis-9 18:1, trans-11 18:1, cis-9,trans-11 CLA, 18:2 n-6, and 18:3n-3 in milk (Figure 1). Fresh grass also increased $(P<0.03)$ the secretion of $3 \mathrm{~S}, 7 \mathrm{R}, 11 \mathrm{R}, 15-$ tetramethyl-16:0 and unresolved cis-11 $16: 1$ and 3R,7R,11R,15-tetramethyl-16:0 in milk relative to hay $[0.9$ vs. $0.6(\mathrm{SE}=0.09)$ and 4.4 vs. $2.7(\mathrm{SE}=0.35)$ $\mathrm{mmol} / \mathrm{d}$, respectively].

Grass Hay Versus Grass Silage. Feeding hay or grass silages of different fermentation characteristics resulted in relatively minor, albeit often significant differences in milk FA composition. Relative to hay, grass silages increased $(P<0.01)$ 4:0 and 6:0 concentrations and decreased $(P<0.05) 12: 0$ and 14:0 content (Table $9)$. Forage conservation method had no effect $(P>$ 0.10 ) on milk 16:0 concentration (Table 9), whereas grass silages lowered $(P<0.03)$ the concentrations of cis-9 $16: 1$ and several trans-16:1 $(\Delta 9,10,12)$ isomers compared with hay (Supplemental Table S2, available online at http://www.journalofdairyscience.org/). Relative to hay, grass silage decreased $(P<0.01)$ milk fat 18:2n-6 content and tended $(P=0.08)$ to lower $18: 3 \mathrm{n}-3$ concentrations (Table 9$)$. Grass silages also increased $(P$ $<0.05)$ milk fat 18:0 (Table 9) and trans-18:1 ( $\Delta 12-16$; Supplemental Table S1) content and the concentration of several 18-carbon PUFA including cis-9,trans-13+ cis-10,trans-14 18:2, trans-11,cis-15 18:2, $\Delta 9,12$ 18:2, $\Delta 12,15$ 18:2, and cis-9,trans-11,cis-15 18:3 compared with hay (Table 9; Supplemental Table S1). Treatments 
Table 6. Effect of fresh grass or conserved forages on the FA composition of NEFA in arterial blood of lactating cows

\begin{tabular}{|c|c|c|c|c|c|c|c|c|c|c|}
\hline \multirow[b]{2}{*}{$\mathrm{FA}, \mathrm{g} / 100 \mathrm{~g}$ of $\mathrm{FA}$} & & & & & \multicolumn{6}{|c|}{ Experiment 2} \\
\hline & Grass & Hay & $\mathrm{SEM}^{1}$ & $P$-value & Hay & $\mathrm{UTS}^{2}$ & FAS $^{3}$ & $\mathrm{SEM}^{4}$ & Method & Extent \\
\hline $12: 0$ & 0.16 & 0.34 & 0.074 & 0.08 & 0.38 & 0.22 & 0.29 & 0.080 & 0.25 & 0.58 \\
\hline $13: 0$ & 1.40 & 2.60 & 0.281 & 0.013 & 1.03 & 0.91 & 0.77 & 0.055 & 0.032 & 0.12 \\
\hline $14: 0$ & 0.97 & 1.11 & 0.130 & 0.35 & 1.13 & 1.19 & 1.27 & 0.087 & 0.35 & 0.53 \\
\hline anteiso 15:0 & 0.42 & 0.65 & 0.078 & 0.042 & 0.52 & 0.52 & 0.61 & 0.069 & 0.43 & 0.26 \\
\hline iso $15: 0$ & 0.42 & 0.59 & 0.070 & 0.07 & 0.55 & 0.54 & 0.48 & 0.071 & 0.56 & 0.40 \\
\hline $16: 0$ & 15.3 & 11.1 & 1.23 & 0.027 & 12.7 & 12.7 & 14.4 & 0.580 & 0.30 & 0.09 \\
\hline cis-9 16:1 & 1.13 & 0.72 & 0.167 & 0.07 & 0.55 & 0.43 & 0.69 & 0.073 & 0.95 & 0.045 \\
\hline $17: 0$ & 0.65 & 0.58 & 0.110 & 0.58 & 1.56 & 0.81 & 0.98 & 0.398 & 0.15 & 0.71 \\
\hline anteiso $17: 0$ & 0.74 & 0.63 & 0.132 & 0.45 & 0.67 & 0.54 & 0.67 & 0.057 & 0.35 & 0.13 \\
\hline iso $17: 0$ & 0.26 & 0.35 & 0.082 & 0.38 & 0.34 & 0.42 & 0.38 & 0.091 & 0.23 & 0.39 \\
\hline cis-9,trans-11 CLA $^{6}$ & 0.22 & 0.60 & 0.230 & 0.17 & 1.66 & 1.74 & 1.48 & 0.190 & 0.81 & 0.31 \\
\hline $18: 3 n-3$ & 4.33 & 5.53 & 1.030 & 0.31 & 3.84 & 3.83 & 3.11 & 0.600 & 0.64 & 0.43 \\
\hline $18: 3 n-6$ & 0.25 & 0.65 & 0.076 & 0.007 & 0.37 & 0.39 & 0.31 & 0.037 & 0.70 & 0.19 \\
\hline $18: 4 n-3$ & 0.00 & 0.33 & 0.094 & 0.026 & 0.20 & 0.23 & 0.16 & 0.036 & 0.92 & 0.19 \\
\hline 20:0 & 0.92 & 1.36 & 0.196 & 0.10 & 1.55 & 1.54 & 1.38 & 0.098 & 0.49 & 0.30 \\
\hline 3S,7R,11R,15-tetramethyl-16:0 & 0.54 & 0.57 & 0.085 & 0.75 & 0.82 & 2.13 & 1.34 & 0.228 & 0.016 & 0.048 \\
\hline $3 \mathrm{R}, 7 \mathrm{R}, 11 \mathrm{R}, 15$-tetramethyl-16:0 & 0.99 & 0.75 & 0.237 & 0.35 & 1.04 & 1.22 & 0.92 & 0.238 & 0.86 & 0.20 \\
\hline $20: 3 n-6$ & 0.23 & 0.39 & 0.080 & 0.13 & 0.32 & 0.29 & 0.20 & 0.065 & 0.42 & 0.37 \\
\hline $20: 4 n-3$ & 0.20 & 0.28 & 0.015 & 0.007 & 0.21 & 0.20 & 0.05 & 0.028 & 0.045 & 0.010 \\
\hline $20: 4 n-6$ & 0.27 & 0.42 & 0.056 & 0.06 & 0.33 & 0.29 & 0.25 & 0.052 & 0.42 & 0.60 \\
\hline $20: 5 n-3$ & 0.32 & 0.47 & 0.069 & 0.10 & 0.36 & 0.31 & 0.42 & 0.010 & 0.95 & 0.25 \\
\hline 21:0 & 0.48 & 0.79 & 0.191 & 0.17 & 1.04 & 1.09 & 1.04 & 0.159 & 0.80 & 0.73 \\
\hline $22: 0$ & 0.94 & 1.39 & 0.234 & 0.13 & 1.46 & 1.64 & 1.54 & 0.142 & 0.40 & 0.54 \\
\hline cis-14 23:1 & 0.25 & 0.25 & 0.073 & 0.96 & 0.52 & 0.62 & 0.63 & 0.125 & 0.10 & 0.79 \\
\hline
\end{tabular}

${ }^{1}$ Standard error of the mean for $\mathrm{n}=10$ measurements; error degree of freedom $=4$.

${ }^{2}$ Untreated silage.

${ }^{3}$ Silage ensiled using a formic acid-based additive.

${ }^{4}$ Standard error of the mean for $\mathrm{n}=15$ measurements; error degree of freedom $=6$.

${ }^{5}$ Significance of effect due to forage conservation method (drying vs. ensiling; method) or extent of silage fermentation (extensively vs. restrictively fermented silage; extent).

${ }^{6} \mathrm{CLA}=$ conjugated linoleic acid.

had no effect $(P>0.10)$ on milk cis-9,trans-11 CLA concentrations (Table 9). Relative to hay, silages resulted in higher $(P<0.01)$ milk fat trans-12,trans-14 CLA, trans-13,cis-15 CLA, and $\Delta 11,13$ CLA concentrations, and lower $(P<0.02)$ trans-8,cis-10 CLA, and trans10,cis-12 CLA content (Supplemental Table S1). Grass silages also decreased $(P \leq 0.05)$ the concentration of several 20- and 22-carbon PUFA in milk fat (Table 9), and the majority of 13- to 18-carbon iso and anteiso FA compared with hay (Supplemental Table S3).

Relative to hay, grass silages had no effect on the secretion of $18: 2 \mathrm{n}-6$ and $18: 3 \mathrm{n}-3$ in milk $(P>0.05)$, but increased $(P \leq 0.05)$ 14:0, 16:0, 18:0, trans-11 18:1, and cis-9,trans-11 CLA output (Figure 2). Grass silages also increased $(P<0.01)$ the secretion of $3 \mathrm{~S}, 7 \mathrm{R}, 11 \mathrm{R}, 15-$ tetramethyl-16:0 in milk compared with hay $[0.9,2.7$, and $2.9(\mathrm{SE}=0.41) \mathrm{mmol} / \mathrm{d}$, for hay, UTS, and FAS, respectively].

Extent of Silage Fermentation. Restricting fermentation in silo resulted in higher $(P<0.04)$ milk 18:0 and trans-11 18:1 content, but had no effect $(P>0.10)$ on cis-9,trans-11 CLA, 18:2n-6, and 18:3n-3 concentrations (Table 9). Compared with UTS, FAS increased $(P \leq 0.05)$ trans-9,cis-12 18:2, trans-11,cis-15 18:2, 
Table 7. Effect of fresh grass or conserved forages on the uptake and balance of FA across the mammary glands of lactating cows

\begin{tabular}{|c|c|c|c|c|c|c|c|c|c|c|}
\hline Item & \multicolumn{4}{|c|}{ Experiment 1} & \multicolumn{6}{|c|}{ Experiment 2} \\
\hline \multicolumn{11}{|c|}{ Mammary FA uptake, $\mathrm{mmol} / \mathrm{d}$} \\
\hline $12: 0$ & 2.97 & 4.29 & 1.568 & 0.45 & 3.05 & 4.91 & 4.23 & 0.837 & 0.31 & 0.17 \\
\hline $14: 0$ & 28.6 & 35.2 & 4.59 & 0.23 & 28.6 & 21.2 & 26.7 & 4.59 & 0.42 & 0.41 \\
\hline cis-9 16:1 & 28.7 & 11.8 & 7.15 & 0.08 & 4.53 & 3.63 & 3.44 & 1.773 & 0.67 & 0.95 \\
\hline 18:0 & 793 & 555 & 70.0 & 0.028 & 671 & 769 & 883 & 96.0 & 0.07 & 0.21 \\
\hline cis-9 18:1 & 506 & 107 & 67.0 & 0.004 & 111 & 149 & 133 & 19.7 & 0.27 & 0.60 \\
\hline$\Sigma$ cis- $18: 1$ & 545 & 136 & 72.7 & 0.005 & 134 & 188 & 174 & 21.5 & 0.13 & 0.66 \\
\hline trans-10 18:1 & 3.67 & 2.41 & 0.900 & 0.24 & 4.20 & 4.83 & 7.78 & 1.149 & 0.18 & 0.12 \\
\hline trans-11 18:1 & 61.0 & 28.4 & 6.94 & 0.010 & 36.7 & 44.0 & 52.5 & 5.98 & 0.10 & 0.26 \\
\hline $18: 2 \mathrm{n}-6$ & 39.3 & 33.1 & 4.81 & 0.27 & 43.8 & 39.1 & 45.4 & 7.97 & 0.89 & 0.60 \\
\hline $\mathrm{g} / \mathrm{d}$ & 636 & 371 & 44.7 & 0.005 & 426 & 459 & 518 & 50.6 & 0.18 & 0.26 \\
\hline \multicolumn{11}{|c|}{ Mammary FA balance, $\mathrm{mmol} / \mathrm{d}$} \\
\hline 4:0 & 346 & 312 & 16.5 & 0.11 & 390 & 458 & 549 & 49.2 & $<0.001$ & $<0.001$ \\
\hline $6: 0$ & 161 & 159 & 10.0 & 0.84 & 195 & 216 & 251 & 21.4 & $<0.001$ & 0.001 \\
\hline 8:0 & 82.3 & 83.1 & 5.87 & 0.89 & 97.2 & 104 & 119 & 0.81 & 0.002 & 0.003 \\
\hline 10:0 & 161 & 176 & 10.4 & 0.23 & 199 & 200 & 218 & 20.9 & 0.14 & 0.038 \\
\hline cis-9 10:1 & 17.4 & 21.2 & 2.17 & 0.16 & 21.2 & 23.3 & 25.6 & 2.37 & 0.05 & 0.19 \\
\hline $12: 0$ & 163 & 190 & 11.1 & 0.08 & 205 & 201 & 217 & 21.3 & 0.62 & 0.12 \\
\hline cis-9 12:1 & 0.00 & 0.01 & 0.001 & 0.07 & 0.01 & 0.01 & 0.01 & 0.001 & 0.92 & 0.94 \\
\hline $14: 0$ & 467 & 506 & 32.9 & 0.31 & 589 & 608 & 651 & 54.1 & 0.015 & 0.021 \\
\hline cis-9 14:1 & 45.0 & 56.8 & 4.98 & 0.08 & 56.0 & 55.6 & 55.6 & 4.95 & 0.93 & 0.99 \\
\hline $16: 0$ & 601 & 1,072 & 67.2 & 0.003 & 1,225 & 1,295 & 1,364 & 130.4 & 0.06 & 0.23 \\
\hline cis-9 16:1 & 44.8 & 59.2 & 4.89 & 0.043 & 60.4 & 59.0 & 60.4 & 5.98 & 0.80 & 0.66 \\
\hline $18: 0$ & -437 & -340 & 54.5 & 0.15 & -359 & -405 & -448 & 72.2 & 0.32 & 0.58 \\
\hline$\Sigma<16$-carbon & 2,123 & 2,671 & 139.6 & 0.018 & 3,174 & 3,400 & 3,631 & 280.4 & 0.003 & 0.029 \\
\hline$\Sigma \overline{18}$-carbon & -10.3 & 86.2 & 86.4 & 0.33 & 36.6 & -17.7 & 33.7 & 64.48 & 0.66 & 0.50 \\
\hline$\Sigma$ SFA & 1,514 & 2,141 & 131.2 & 0.009 & 2,501 & 2,690 & 2872 & 263.2 & 0.042 & 0.20 \\
\hline$\Sigma$ MUFA & 526 & 574 & 70.1 & 0.54 & 551 & 523 & 626 & 62.5 & 0.48 & 0.026 \\
\hline$\Sigma$ PUFA & 52.0 & 41.5 & 20.07 & 0.63 & 13.9 & 33.7 & 32.6 & 24.0 & 0.54 & 0.98 \\
\hline \multicolumn{11}{|l|}{$\Sigma \mathrm{FA}$} \\
\hline $\mathrm{mmol} / \mathrm{d}$ & 2,087 & 2,753 & 120.5 & 0.006 & 3,060 & 3,237 & 3,516 & 334.5 & 0.031 & 0.08 \\
\hline $\mathrm{g} / \mathrm{d}$ & 402 & 579 & 24.1 & 0.002 & 620 & 651 & 696 & 71.7 & 0.15 & 0.26 \\
\hline
\end{tabular}

${ }^{1}$ Standard error of the mean for $\mathrm{n}=10$ measurements; error degree of freedom $=4$.

${ }^{2}$ Untreated silage.

${ }^{3}$ Silage ensiled using a formic acid-based additive.

${ }^{4}$ Standard error of the mean for $\mathrm{n}=15$ measurements; error degree of freedom $=6$.

${ }^{5}$ Significance of effect due to forage conservation method (drying vs. ensiling; method) or extent of silage fermentation (extensively vs. restrictively fermented silage; extent).

${ }^{6} \mathrm{CLA}=$ conjugated linoleic acid.

and trans-11,cis-13 CLA concentrations (Supplemental Table S1, available online at http://www.journalofdairyscience.org/), but had relatively minor effects on the abundance of odd- and branched-chain FA in milk (Supplemental Table S3). Relative to UTS, FAS resulted in higher $(P<0.05)$ secretion of trans-11 18:1, cis-9,trans-11 CLA, 18:2n-6, and 18:3n-3 in milk (mean responses $+35,+26,+13$, and $+10 \%$, respectively; Fig- 
Table 8. Effect of fresh grass or conserved forages on the proportion of medium-chain FA secreted in milk fat originating from synthesis de novo and desaturation in the mammary glands of lactating cows

\begin{tabular}{|c|c|c|c|c|c|c|c|c|c|c|}
\hline FA & \multicolumn{4}{|c|}{ Experiment 1} & \multicolumn{6}{|c|}{ Experiment 2} \\
\hline \multicolumn{11}{|c|}{ De novo synthesis, $\%$} \\
\hline $12: 0$ & 98.0 & 97.8 & 0.903 & 0.77 & 98.5 & 97.3 & 98.6 & 0.52 & 0.42 & 0.10 \\
\hline 14:0 & 93.9 & 93.5 & 1.383 & 0.80 & 95.3 & 96.4 & 96.1 & 0.80 & 0.21 & 0.73 \\
\hline $10: 0$ & 9.88 & 10.9 & 0.548 & 0.15 & 9.83 & 10.6 & 10.6 & 0.66 & 0.17 & 0.97 \\
\hline $12: 0$ & 0.0027 & 0.0032 & 0.00024 & 0.11 & 0.0028 & 0.0028 & 0.0026 & 0.00011 & 0.61 & 0.31 \\
\hline $14: 0$ & 8.31 & 9.55 & 0.411 & 0.040 & 8.40 & 8.16 & 7.66 & 0.479 & 0.40 & 0.45 \\
\hline 16:0 & 3.94 & 4.18 & 0.330 & 0.51 & 3.78 & 3.49 & 3.41 & 0.205 & 0.07 & 0.65 \\
\hline 18:0 & 55.1 & 68.5 & 4.02 & 0.029 & 53.1 & 48.9 & 43.6 & 4.02 & 0.22 & 0.39 \\
\hline trans-11 18:1 & 28.1 & 34.1 & 4.82 & 0.28 & 19.5 & 19.4 & 18.6 & 2.97 & 0.91 & 0.86 \\
\hline $20: 0$ & 45.1 & 51.8 & 16.5 & 0.71 & 37.5 & 42.0 & 43.9 & 4.87 & 0.31 & 0.76 \\
\hline
\end{tabular}

${ }^{1}$ Standard error of the mean for $\mathrm{n}=10$ measurements; error degree of freedom $=4$.

${ }^{2}$ Untreated silage.

${ }^{3}$ Silage ensiled using a formic acid-based additive.

${ }^{4}$ Standard error of the mean for $\mathrm{n}=15$ measurements; error degree of freedom $=6$.

${ }^{5}$ Significance of effect due to forage conservation method (drying vs. ensiling; method) or extent of silage fermentation (extensively vs. restrictively fermented silage; extent).

ure 2), but had no effect $(P>0.10)$ on the output of 3,7,11,15-tetramethyl-16:0 in milk (data not presented).

\section{DISCUSSION}

Numerous studies have demonstrated that the conservation of forage alters milk fat composition (Dewhurst et al., 2006; Elgersma et al., 2006; Chilliard et al., 2007). However, in most cases, investigations of the influence of conservation method are confounded with differences in forage maturity that alter the distribution and abundance of lipid in forage crops (Dewhurst et al., 2006; Elgersma et al., 2006). Novel aspects of this experiment included measurements of plasma lipids, mammary lipid metabolism, and milk fat composition in cows fed diets based on fresh grass or conserved forages prepared simultaneously from the same grass leys. Furthermore, the same grass hay was fed in both experiments, allowing for indirect inferences on the effects of silages relative to fresh grass in the absence of differences in forage maturity or chop length. Nevertheless, the experimental design used in experiment 1 can be criticized due to the confounding effects of treatment with time. However, during established lactation, timedependent effects on milk FA composition in cows fed the same diet are marginal (Roy et al., 2006; Mohammed et al., 2011) relative to the effects that can be expected due to forage conservation.

\section{Milk Production}

Fresh Grass Versus Grass Hay. Forage conservation method tends to have inconsistent effects on milk production and composition, with differences often being related to the effects on energy intake, rumen metabolism, and nutrient partitioning (Huhtanen, 1998; Lock and Shingfield, 2004). Energy intake and milk yield did not differ between diets based on fresh grass or hay, whereas zero grazing resulted in a higher output of fat in milk. Differences in milk fat secretion were not accompanied by alterations in the mammary blood flow (11,320 and 11,323 L/d for fresh grass and hay, respectively), suggesting that the increase in mammary lipogenesis associated with zero grazing was related to a greater uptake of preformed FA across the mammary glands rather than differences in milk volume per se.

Grass Hay Versus Grass Silage. Grass silages increased energy intake, milk yield, and milk fat output compared with hay. Increased synthesis of FA de novo in the mammary glands for silages was associated with higher BHBA concentrations in the peripheral circulation, which is often the case in cows fed diets based on grass silage compared with grass hay (Shingfield et al., 2002b; Ferlay et al., 2006). Under the specified conditions of this experiment, higher concentrations of BHBA in arterial blood of cows fed silages compared with hay were accompanied by increases in the molar proportions of butyric acid in rumen VFA (HalmemiesBeauchet-Filleau et al., 2013).

Extent of Silage Fermentation. Restricting fermentation in silo increased milk fat yield, principally due to greater synthesis of 4:0 to 10:0 and 14:0 in the mammary glands. For grasses grown in Northern European climates, ensilage of grass using a formic acid- 
Table 9. Effect of fresh grass or conserved forages on milk FA composition in lactating cows

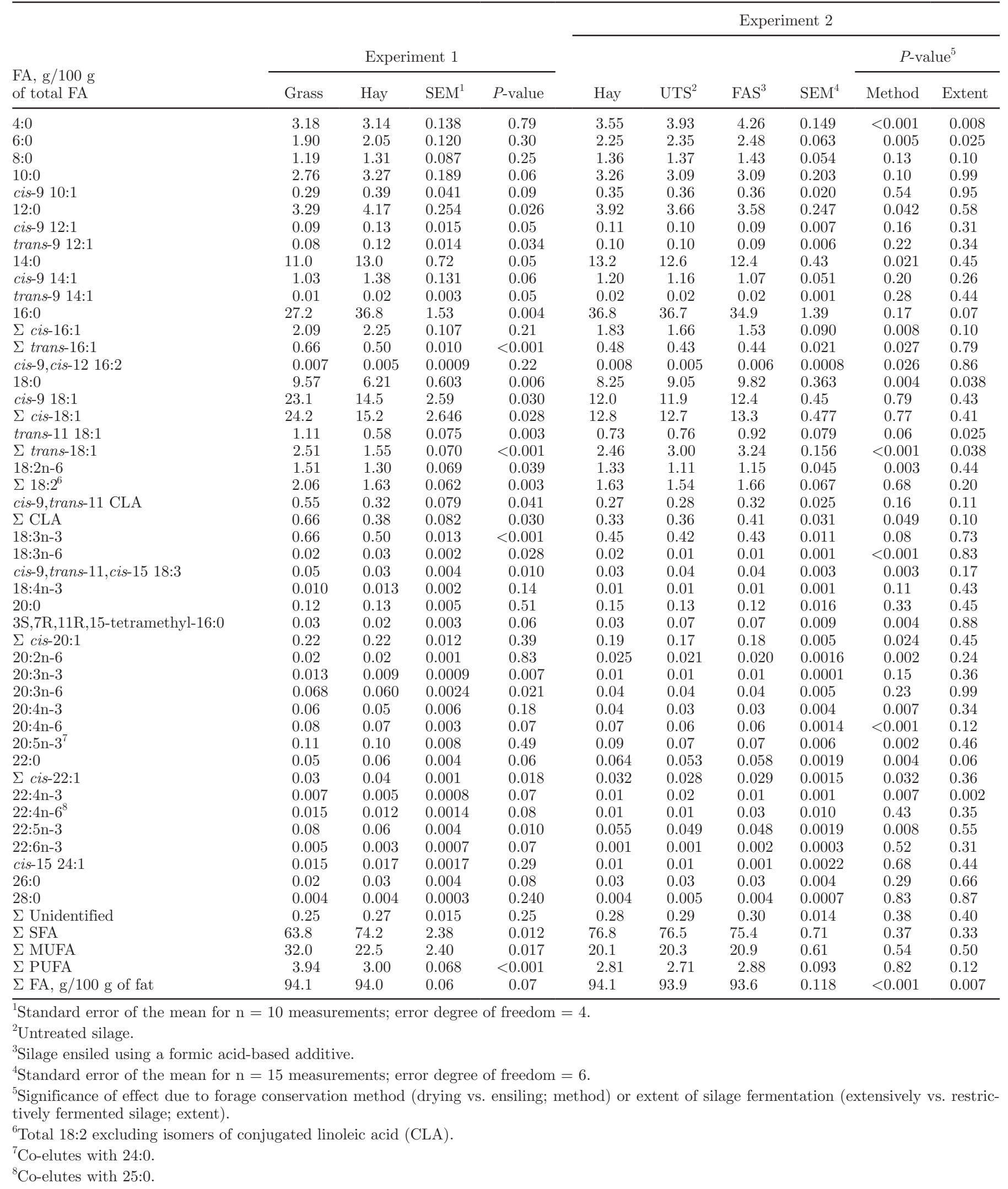




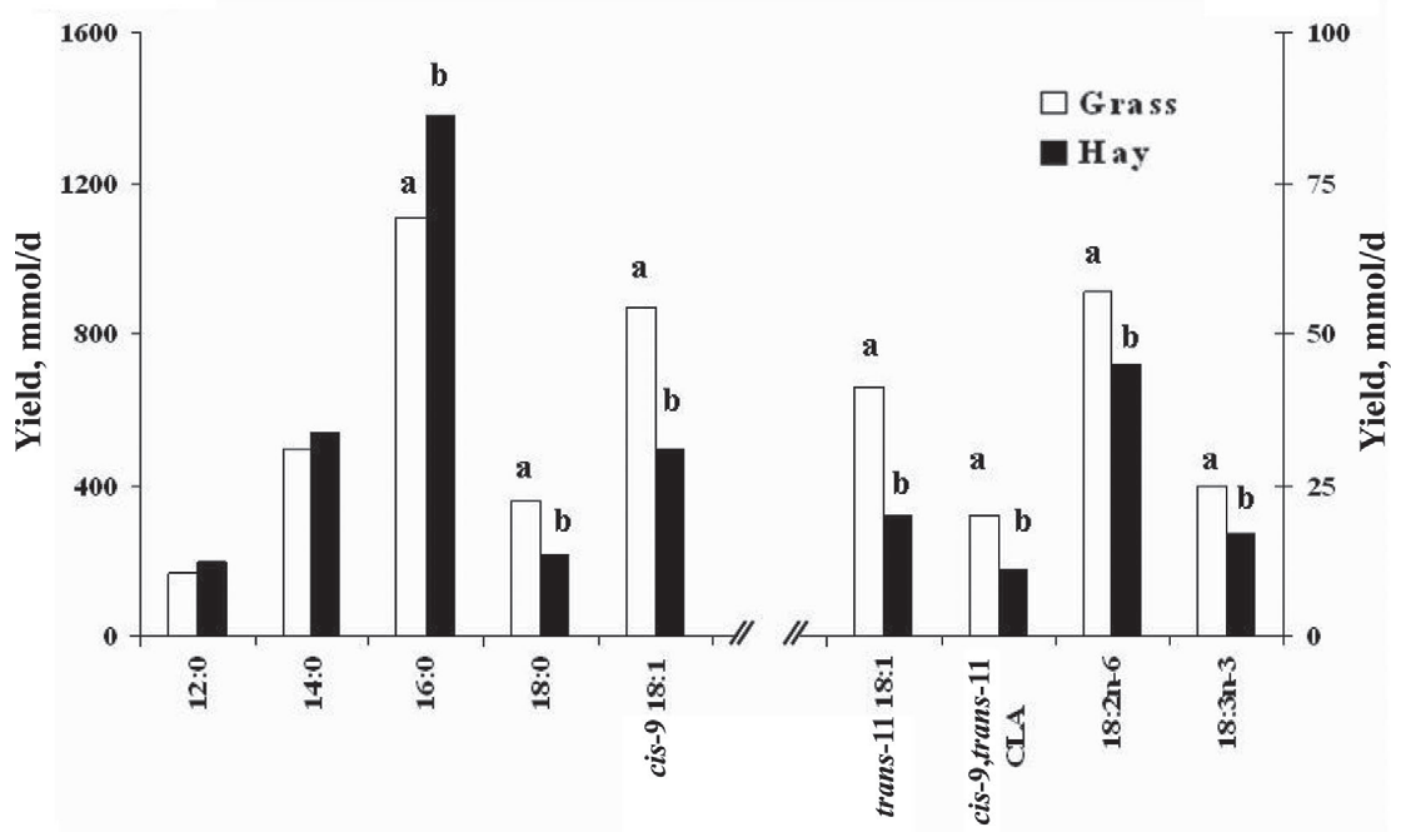

Figure 1. Effect of fresh grass or grass hay on the secretion of specific FA in milk of lactating cows. Bars without a common letter (a and b) differ $(P<0.05)$. CLA $=$ conjugated linoleic acid.

based additive typically increases milk protein yield through improvements in DMI and the energy efficiency of microbial protein synthesis in the rumen (Huhtanen 1998; Lock and Shingfield, 2004). In the present study, increases in milk protein yield for FAS compared with UTS were associated with higher ME intakes, in the absence of higher flows of microbial protein at the omasum (data not presented).

\section{Concentration of Plasma Lipids and Metabolites}

Plasma glucose concentrations were relatively constant within and between experiments, whereas BHBA and urea concentrations exhibited more variation, with all metabolites being in the range expected for cows offered diets containing relatively high proportions of forage (Miettinen and Huhtanen, 1997; Kay et al.,

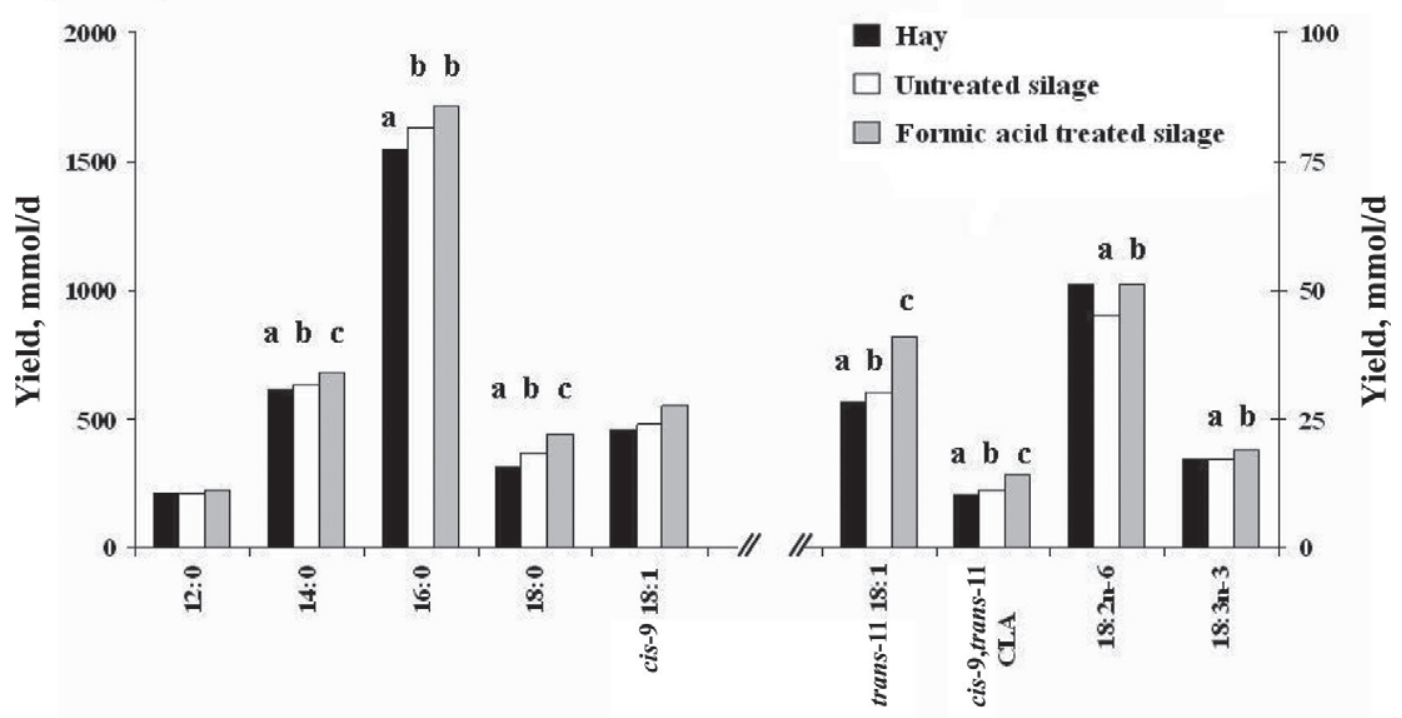

Figure 2. Effect of grass hay and restrictively or extensively fermented grass silage on the secretion of specific FA in milk of lactating cows. Bars without a common letter $(\mathrm{a}-\mathrm{c})$ differ $(P<0.05)$. CLA $=$ conjugated linoleic acid. 
2005; Ferlay et al., 2006). Consistent with the known distribution of lipid fractions in bovine plasma (Offer et al., 2001; Tyburczy et al., 2008), circulating CE and PL represented the major FA repositories, whereas the concentrations of FA in TAG and NEFA were more than an order of magnitude lower. It is well established that the profile of lipoproteins in bovine plasma is characterized by extremely low concentrations of chylomicrons, very low-density lipoproteins, and total TAG, whereas more than $90 \%$ of FA in plasma are transported principally as $\mathrm{CE}$ and PL components of high-density lipoproteins (Palmquist, 1976; Moore and Christie, 1979).

Across all diets, concentrations of PL, CE, and total FA in arterial blood were associated with changes in the flow of total $\mathrm{FA}$ at the omasum $\left(\mathrm{r}^{2}\right.$ values 0.27 to 0.34 ), whereas no relation existed for arterial NEFA and TAG fractions. Earlier investigations in lactating cows also reported a close relationship between the amount of FA absorbed in the intestine and total FA content of venous blood in lactating cows, but not for individual NEFA, TAG, CE, or PL fractions (Glasser et al., 2007). Similarly, dietary oilseed supplements were found to progressively increase CE and PL concentrations in the peripheral circulation of growing cattle, but have no influence on plasma TAG or apolipoprotein B (Scislowski et al., 2005). These findings highlight that the regulation of circulating lipid fractions is not solely dependent on the absorption of FA, but involves the coordinate and highly regulated catabolism and synthesis of FA in body tissues, and the overall balance between the entry and removal of lipids from the circulatory system (Christie, 1981; Bauchart, 1993).

Fresh Grass Versus Grass Hay. Zero grazing resulted in higher concentrations of PL and TAG in arterial blood, increases that were of a similar magnitude to numerical differences in the flow of total FA at the omasum (437 and $365 \mathrm{~g} / \mathrm{d}$ for fresh grass and hay, respectively; Halmemies-Beauchet-Filleau et al., 2013), suggesting that changes in the supply of medium- and long-chain FA may have contributed to the alterations in the concentration of circulating lipid fractions associated with forage conservation method. Even though all lipid fractions in blood are influenced by changes in FA supply within a few days, changes in the concentrations of TAG and NEFA are far more transitory compared with PL and CE fractions (Moore and Christie, 1979). In lactating cows, an interval of $45 \mathrm{~d}$ or more may be required for plasma $\mathrm{PL}$ and $\mathrm{CE}$ concentration responses to increases in FA supply to reach a plateau (Scislowski et al., 2005). It therefore follows that forage conservation may have a greater influence on the concentration and composition of plasma $\mathrm{CE}$ and $\mathrm{PL}$ fractions when diets are fed over an interval longer than the 14-d experimental periods implemented in the pres- ent study. Furthermore, the much slower turnover of FA transported in the blood within CE and PL fractions serves to highlight the importance of previous nutritional status in attempts to define the relation between FA supply and plasma lipid content and composition.

Relative differences in arterial NEFA concentrations in cows fed fresh grass or hay were much larger compared with the differences in total FA at the omasum (Halmemies-Beauchet-Filleau et al., 2013). Several studies have reported that grazing results in higher plasma NEFA concentrations compared with conserved forages, differences that have been attributed to lower circulating insulin concentrations (Agenäs et al., 2002; Kay et al., 2005). However, circulating NEFA concentrations are also elevated during periods of nutrient restriction in lactating cows as a consequence of more extensive lipolysis and lowered lipogenesis in adipose (Chilliard et al., 2000). Intakes of ME were similar for diets based on fresh grass and hay, whereas zero grazing resulted in a $9.8 \mathrm{MJ} / \mathrm{d}$ increase in milk energy secretion, differences that were only partially compensated for by +2.9 and +3.5 percentage unit improvements in total-tract OM and NDF digestibility, respectively (Halmemies-Beauchet-Filleau et al., 2013). As a result, fresh grass resulted in a much lower, albeit slightly positive calculated energy balance compared with hay. Even though experimental periods were relatively short, the differences in energy secretion in milk, calculated energy balance, and higher uptakes of 16:0+ cis-9 16:1 and 18:0 + cis-9 18:1 across the mammary glands relative to the flow of these FA at the omasum suggest that alterations in the metabolism of lipids in peripheral tissues also contributed to the effects of forage conservation on mammary lipid metabolism and milk FA composition. Direct comparisons of FA uptake across the mammary glands with the flow of total FA at the omasum (mean +199 and $+6 \mathrm{~g} / \mathrm{d}$ for fresh grass and hay, respectively), indicate that medium- and longchain FA used for the synthesis of milk fat also originated from body tissues, with the apparent contribution being much greater during zero grazing. More extensive mobilization of adipose also offers an explanation for the elevated concentrations of PL, TAG, and NEFA in arterial blood for fresh grass compared with hay.

Grass Hay Versus Grass Silage. Compared with hay, grass silages resulted in higher concentrations of PL and TAG in arterial blood that were accompanied by higher flows of total FA at the omasum $(422,551$, and $587 \mathrm{~g} / \mathrm{d}$, for hay, UTS, and FAS, respectively; Halmemies-Beauchet-Filleau et al., 2013), with the implication that alterations in the amount of FA available for absorption may contribute to the influence of conservation method on plasma lipid fractions. However, drying rather than ensiling of grass had no influence 
on plasma NEFA or glucose concentrations, which are often similar in lactating cows fed grass hay and grass silage (Shingfield et al., 2002b; Ferlay et al., 2006).

Extent of Silage Fermentation. Restricting fermentation in silo increased NEFA concentrations in the peripheral circulation, whereas in earlier reports, methods used for the ensilage of a mixture of timothy and meadow fescue had little an influence on arterial TAG or NEFA concentrations of lactating cows (Miettinen and Huhtanen, 1997). Diets based on restrictively fermented silage typically supply lower amounts of gluconeogenetic precursors than extensively fermented grass silages (Huhtanen, 1998), whereas differences in the extent of fermentation in silo in this study had no influence on plasma glucose concentrations.

\section{FA Composition of Plasma Lipids}

The amount and relative abundance of FA is known to differ between isolated plasma lipid fractions in ruminants (Christie, 1981; Bauchart, 1993). Plasma TAG and NEFA fractions contained relatively high proportions of 16:0 and 18:0, and cis-9 18:1, 16:0, 18:0, cis-9 18:1, and 18:2n-6 were abundant in PL, whereas $18: 2 n-6$ and $18: 3 n-3$ were the major constituents of CE fractions, a distribution of FA in plasma lipids typical for lactating cows (Offer et al., 2001; Tyburczy et al., 2008). Across both experiments, differences in the relative proportions of trans 18:1 isomers in arterial lipid fractions were associated with changes in the flow at the omasum, consistent with previous reports examining the relation between FA supply and plasma lipid concentrations in lactating cows (Glasser et al., 2007). Comparison of the flow at the omasum and absolute concentrations in arterial blood indicated that the majority of trans-11 18:1 was transported in PL and TAG fractions, whereas CE was apparently the major repository for cis-9,trans-11 CLA. Recovery of ${ }^{13} \mathrm{C}$ labeled trans-11 18:1 administered at the duodenum also indicated that a substantial proportion of absorbed trans-11 18:1 was sequestered into plasma PL fractions in lactating cows (Mosley et al., 2006).

On all diets, 18:2n-6 and 18:3n-3 represented, on average, 39 and $11 \mathrm{~g} / 100 \mathrm{~g}$ of total FA in arterial blood, respectively, but only 3.8 and $1.7 \mathrm{~g} / 100 \mathrm{~g}$ of FA at the omasum. No significant associations were identified between 18:2n- 6 and 18:3n-3 at the omasum and enrichment in lipid fractions or total concentrations in arterial blood, other than the amount of 18:3n-3 transported in TAG fractions. These findings reflect both the limited influence of treatments on the availability of 18:2n-6 and 18:3n-3 for absorption (HalmemiesBeauchet-Filleau et al., 2013), as well as the sparing of essential FA for vital biological functions and possible remodeling of FA components of plasma lipid fractions in the liver (Noble, 1984; Christie et al., 1986; Chilliard et al., 2007).

Concentrations of 16:0, 18:0, and cis-9 18:1 in arterial blood for all cows were associated with changes in the flow of these FA at the omasum. However, significant positive intercepts for these relationships indicate that dietary intake and synthesis of FA de novo by rumen bacteria are not the sole determinants of these FA in arterial blood of lactating cows in positive calculated energy balance. Other factors including selective retention, de novo synthesis, elongation, desaturation, deposition, and mobilization of these FA in several tissues including adipocytes and enterocytes (Chilliard et al., 2007; Glasser et al., 2007; Shingfield et al., 2013), as well as differences in the relative entry and removal rate from the circulation may also influence plasma 16:0, 18:0, and cis-9 18:1 concentrations.

Plasma CE were devoid of 3,7,11,15-tetramethyl-16:0, whereas limited amounts of both diastereomers were incorporated into other lipid fractions, with PL being the major repository in arterial blood, which is in agreement with much earlier reports (Lough, 1977). Diastereomers of 2,6,10,14-tetramethyl-15:0 were recovered exclusively in TAG with a SRR/RRR ratio similar to that of 3,7,11,15-tetramethyl-16:0, suggesting that 2,6,10,14-tetramethyl-15:0 is formed during $\alpha$-oxidation of 3,7,11,15-tetramethyl-16:0 in the bovine liver, as is known to occur in humans (Verhoeven et al., 1997).

Fresh Grass Versus Grass Hay. Fresh grass increased the abundance of 18:2n-6 in TAG and 18:3n-3 in TAG and CE compared with hay, despite similar flows of 18:2n-6 and 18:3n-3 at the omasum (Halmemies-Beauchet-Filleau et al., 2013). Changes in the availability of $18: 2 \mathrm{n}-6$ and $18: 3 \mathrm{n}-3$ are known to rapidly influence the composition of TAG and NEFA in plasma, whereas incorporation into PL and CE occurs at a lower rate, although enrichment in these fractions persists over a longer period (Christie, 1981; Noble, 1984). Apparent transfer of 18:2n-6 and 18:3n-3 from the omasum into milk was numerically higher for cows fed fresh grass (89 and $71 \%$, respectively) compared with hay (corresponding values 74 and 64\%), which, along with more extensive total-tract OM digestion (HalmemiesBeauchet-Filleau et al., 2013), may indicate higher bioavailability of PUFA for diets based on fresh grass than hay. Based on responses to postruminal infusions determined in several experiments, ca. $50 \%$ of $18: 2 \mathrm{n}-6$ or 18:3n-3 administered is recovered in milk (Shingfield et al., 2013). It is possible that release of PUFA into the peripheral circulation due to mobilization of tissue lipids may also explain, or at least contribute to the relatively high apparent transfer of PUFA into milk in the present study, particularly during zero grazing. 
In spite of a higher flow at the omasum, enrichment of trans-11 18:1 in all arterial lipid fractions was similar in cows fed fresh grass and hay, whereas absolute concentrations of trans-11 18:1 transported in arterial blood were $65 \%$ higher during zero grazing (0.99 vs. $0.60 \mathrm{mg} / \mathrm{dL}$, for fresh grass and hay, respectively). Several studies have reported higher enrichment of trans-11 18:1 in total plasma lipids of lactating cows during grazing compared with diets based on conserved forages (Kay et al., 2005; Mohammed et al., 2009). Current data indicated that increases in supply resulted in the enrichment of trans-11 18:1 in PL, TAG, and NEFA fractions, with PL, and to a lesser extent TAG, being the main repositories in lactating cows (Mosley et al., 2006; Tyburczy et al., 2008). In contrast, dietary supplements of fish oil have been reported to increase trans-11 18:1 concentrations of CE in bovine plasma (Offer et al., 2001), but no evidence existed from the present or earlier investigations (Mosley et al., 2006; Tyburczy et al., 2008) to corroborate these findings.

Relative proportions of cis-9 18:1 and 16:0 in arterial NEFA fractions were 158 and $38 \%$ higher in cows fed fresh grass compared with hay. When considered in conjunction with an overall $169 \%$ increase in arterial NEFA concentrations and higher uptake of 16:0 + cis-9 16:1 and 18:0 + cis-9 18:1 across the mammary glands relative to flow at the omasum, this tends to suggest that mobilization of body fat was a significant source of FA entering the peripheral circulation during zero grazing in cows with a near-zero calculated energy balance.

Differences in the relative abundance of diastereomers of 3,7,11,15-tetramethyl-16:0 in plasma PL, TAG, or NEFA between fresh grass and hay were relatively minor. However, absolute concentrations in plasma NEFA fractions were $211 \%$ higher during zero grazing, which could account for the higher secretion of 3,7,11,15-tetramethyl-16:0 diastereomers in milk from fresh grass compared with hay. More extensive uptake across the mammary glands also appears to explain the higher enrichment of 3,7,11,15-tetramethyl-16:0 in milk from pasture or during zero grazing compared with conserved forages (Leiber et al., 2005; Baars et al., 2012).

Grass Hay Versus Grass Silage and Extent of Silage Fermentation. Composition of plasma lipid fractions were similar in cows fed grass hay or grass silages, which is in broad agreement with minimal changes in the flow of total FA at the omasum (Halmemies-Beauchet-Filleau et al., 2013). However, incorporation of 3,7,11,15-tetramethyl-16:0 diastereomers in plasma PL, TAG, and NEFA fractions were higher for cows fed silage compared with hay that reflected the differences in the amount of these FA at the omasum (Halmemies-Beauchet-Filleau et al., 2013). Appearance of 3,7,11,15-tetramethyl-16:0 diastereomers originate from the sequential reduction and oxidation of the phytol moiety of chlorophyll a and b released during microbial digestion of cell walls (Schröder and Vetter, 2011). Current measurements are consistent with ensiling rather than extensive wilting and drying of grass increasing the supply of 3,7,11,15-tetramethyl-16:0 diastereomers available for absorption in lactating cows.

\section{Mammary Lipid Metabolism}

Mammary FA Uptake. Application of the Fick principle to estimate blood flow and uptake of substrates across the mammary glands has the implicit assumption that steady state conditions are reached, whereby blood flow, arterial concentrations, and rate of uptake remain constant (Cant et al., 1993). The technique also assumes that Phe is not metabolized within the mammary glands further than the hydroxylation to Tyr and is reliant on the collection of blood samples that are representative of arterial supply and venous drainage of the mammary glands. Even though the stoichiometric transfer of Phe + Tyr uptake to milk protein appears to hold true, a recent meta-analysis highlighted that the analysis of plasma samples composited over sampling times to estimate arteriovenous differences for Phe and Tyr may introduce errors in the estimation of mammary plasma flow (Lapierre et al., 2012). Despite these limitations and potential sources of error, the technique does allow for quantitative estimates of mammary FA uptake, which, when used in conjunction with the secretion of FA in milk, provides an insight into mammary lipid metabolism.

Measurements of arteriovenous differences and uptake of FA across the mammary glands indicated that, irrespective of forage conservation method, TAG in arterial blood was the major source of preformed FA for milk fat synthesis. Extensive evidence exists from measurements of arteriovenous differences, mammary gland perfusions, and administration of radioactively labeled lipids that the ruminant mammary gland obtains the FA required for the assembly of milk lipids by the action of mammary lipoprotein lipase on the TAG fraction of chylomicrons and very low-density lipoproteins (Palmquist, 1976; Moore and Christie, 1979). Across both experiments, the concentration of TAG or TAG plus NEFA in arterial blood (range 4.3-10.6 and $1.6-11.7 \mathrm{mg} / \mathrm{dL}$ for TAG and NEFA, respectively) were correlated with mammary arteriovenous differences ( $\mathrm{r}$ values of +0.74 and +0.91 , respectively). The magnitude of these associations are similar to those when postruminal infusions have been used to increase FA supply (Enjalbert et al., 1998; Chilliard et al., 2000). Although the mechanisms involved in the transport of FA from the circulation into mammary secretory cells 
have not been fully elucidated, arterial concentrations of specific FA in TAG, and to a lesser extent NEFA, were major determinants of uptake across the mammary glands, with the exception of 18:2n-6. Associations between relative concentrations in arterial $\mathrm{CE}$ and PL fractions and the uptake of individual long-chain FA across the mammary glands were much weaker, which may be related to the low affinity of CE and PL as substrates for lipoprotein lipase (Offer et al., 2001). Overall, current data reinforce the necessity to fractionate lipids in arterial blood for assessing the availability of preformed FA for milk fat synthesis (Palmquist, 1976).

Extraction of TAG or TAG + NEFA and the uptake across the mammary glands could quantitatively account for the secretion of 18:3n-3 in milk, but explained only 70 and $84 \%$ of $18: 2 n-6$ output in milk from fresh grass and conserved forages, respectively. In cows receiving postruminal infusions of plant oils, mammary uptake of 18:2n-6 from arterial TAG and NEFA fractions has, on average, amounted to $56 \%$ of $18: 2 \mathrm{n}-6$ output in milk (Enjalbert et al., 1998). The mammary glands of ruminants are capable of extracting 18-, 20and 22-carbon unsaturated FA of plasma CE and PL fractions in ruminants (Christie et al., 1986; Thivierge et al., 1998), which may explain the apparent shortfall between the uptake and secretion of 18:2n-6. Although extraction of $\mathrm{PL}$ and $\mathrm{CE}$ from arterial blood across the mammary glands was limited, small differences were detected between cows fed hay or grass silages. Given that the concentrations of PUFA in CE and PL are several orders of magnitude higher relative to TAG and NEFA, even minimal extraction of these fractions would constitute a significant contribution to total mammary PUFA uptake. However, accurate determinations of PUFA processed by the mammary glands that originate from limited hydrolysis of arterial CE and PL fractions may well exceed the sensitivity of the arteriovenous technique, as well as measurements of the FA composition of different PL species in arterial and venous blood. In other respects, it is conceivable that limited amounts of 18:2n-6 may well be synthesized endogenously in the bovine mammary glands, based on reports that trans-12 18:1 is desaturated to $18: 2 \mathrm{n}-6$ during incubations with microsomes prepared from the liver of rats (Mahfouz et al., 1980).

Mammary FA Balance. Measurements of arteriovenous differences indicated that de novo synthesis accounted for all 4- to 10-carbon FA secreted in milk fat and 98 and $95 \%$ of 12:0 and 14:0 secretion in milk, respectively, with no significant variation across treatments. In contrast, when compared with fresh grass, forage conservation method altered the relative proportions of 16:0 in milk derived from the peripheral circulation or synthesized in the mammary glands. For cows fed hay or grass silage, de novo synthesis accounted for ca. $79 \%$ of 16:0 secreted in milk, whereas the contribution was much lower (ca. 53\%) during zero grazing. Most accounts indicate that between 39 and $81 \%$ (Palmquist et al., 1969; Bickerstaffe et al., 1974; Enjalbert et al., 1998) of 16:0 in bovine milk fat is synthesized de novo. Although it is generally considered that ca. $50 \%$ of $16: 0$ in milk is synthesized de novo (Chilliard et al., 2000), the current investigation indicated that the synthesis of 16:0 in the mammary glands can be much higher in cows fed diets containing 2 to $3 \%$ FA, with a genetic potential for producing milk with a relatively high fat content.

A lower synthesis of SFA de novo in the mammary glands on fresh grass was associated with higher uptake of 18-, 20-, and 22-carbon unsaturated FA. Increases in the availability of long-chain FA are known to inhibit the activity of acetyl-CoA carboxylase in the ruminant mammary glands (Chilliard et al., 2000). For all diets, the balance of total 18-carbon FA across the mammary glands were close to zero $($ mean $=+26 \pm 5.8 \mathrm{mmol} / \mathrm{d})$, confirming negligible oxidation of long-chain FA in the mammary glands of ruminants fed according to energy requirements (Annison et al., 1968).

Mammary FA Desaturation. Between 44 and $69 \%$ of 18:0 extracted from the peripheral circulation was desaturated in the mammary glands, values that are within the range of previous estimates of between 47 and $78 \%$ in lactating cows (Bickerstaffe et al., 1974; Enjalbert et al., 1998; Mosley and McGuire, 2007). Desaturation of 14:0 and 18:0 in the mammary glands was higher in cows offered hay in experiment 1 compared with other treatments, but the reasons for this are not obvious. Overall, desaturation in the mammary glands contributed, on average, $97,85,72$, and $78 \%$ of cis9 14:1, cis-9 16:1, cis-9 18:1, and cis-9,trans-11 CLA secretion in milk, respectively. Estimates in the present study are in agreement with values determined based on milk fat secretion responses to postruminal infusions of substrates or sterculic oil to inhibit stearoyl-CoA desaturase activity (Palmquist et al., 2005; Mosley et al., 2006; Mosley and McGuire, 2007), or extensive evaluation of the relations between FA at the duodenum and secretion in milk (Glasser et al., 2008).

\section{Milk FA Composition and Secretion}

Fresh Grass Versus Grass Hay. Compared with hay, fresh grass decreased the secretion of 16:0 synthesized de novo, which can be explained by a higher uptake of preformed FA across the mammary glands, which also offers an explanation for milk from pasture containing higher concentrations of 18-carbon FA compared with diets based on conserved forages (Dewhurst 
et al., 2006; Chilliard et al., 2007; Mohammed et al., 2009). Similarly, more-extensive extraction of TAG containing higher proportions of PUFA in arterial plasma, combined with a net uptake of NEFA accounted for the increased abundance and secretion of $18: 2 \mathrm{n}-6$ and 18:3n-3 during zero grazing. Enrichment of 18:3n-3 in milk is typically higher from pasture compared with conserved forages, whereas the effects on 18:2n-6 are inconsistent (Dewhurst et al., 2006; Chilliard et al., 2007; Mohammed et al., 2009). However, comparisons of milk 18:2n-6 content between fresh and conserved forages are often confounded with differences in the forage-toconcentrate ratio of the diet, forage species, or forage maturity (Dewhurst et al., 2006; Mohammed et al., 2009). Overall, the efficiency of transfer of 18:2n-6 (13.7 to $14.4 \%$ ) and $18: 3 \mathrm{n}-3$ (4.8 to $8.5 \%$ ) from the diet into milk was higher for hay than fresh grass, which was related to lowered lipolysis and biohydrogenation in the rumen (Halmemies-Beauchet-Filleau et al., 2013), as well as possible differences in the digestion and absorption of FA in the small intestine.

Higher intakes of unsaturated FA combined with more extensive accumulation of 18-carbon biohydrogenation intermediates in the rumen during zero grazing (Halmemies-Beauchet-Filleau et al., 2013) resulted in higher enrichment of cis 18:1 ( $\Delta 9-16)$, trans 18:1 $(\Delta 6-16)$, $\Delta 11,13$ CLA, $\Delta 13,15$ CLA, $\Delta 9,12$ 18:2, $\Delta 11,15$ 18:2, and cis-9,trans-11,cis-15 18:3 in milk compared with grass hay. Increases in the concentration and output of cis-9 18:1 in milk from fresh grass were associated with higher extraction and uptake of cis-9 18:1 across the mammary glands, at least part of which may be related to more extensive mobilization of tissue adipose.

Secretion of trans-11 18:1 and cis-9,trans-11 CLA in milk was higher from diets based on fresh grass than hay as a consequence of increased uptake of trans-11 18:1 across the mammary glands. Numerous studies have reported higher concentrations of trans-11 18:1 and cis-9,trans-11 CLA in milk from fresh than conserved forages (Dewhurst et al., 2006; Chilliard et al., 2007; Mohammed et al., 2009), and higher concentrations at pasture compared with zero grazing (Leiber et al., 2005; Chilliard et al., 2007; Mohammed et al., 2009). Increases in trans-6+7+8 18:1 at the omasum (Halmemies-Beauchet-Filleau et al., 2013) and uptake across the mammary glands also offers an explanation for the higher enrichment of trans-7,cis-9 CLA in milk on fresh grass compared with hay.

Grass Hay Versus Grass Silages. Diets based on silages resulted in marginally lower milk fat 18:2n6 and 18:3n- 3 concentrations relative to hay, but the secretion of these PUFA did not differ across treatments despite the higher flow of 18:3n-3 at the omasum in cows fed silage (Halmemies-Beauchet-Filleau et al.,
2013). In earlier studies, ensiling decreased (Shingfield et al., 2005) or resulted in similar (Ferlay et al., 2006) concentrations of 18:2n-6 and 18:3n-3 in milk compared with hay. Higher 18-carbon PUFA intakes and greater accumulation of biohydrogenation intermediates in the rumen (Halmemies-Beauchet-Filleau et al., 2013) for silages than for hay were associated with higher concentrations of 18:0, trans 18:1 $(\Delta 12-16)$, trans11,cis-15, $\Delta 9,12$ 18:2, $\Delta 12,15$ 18:2, $\Delta 13,15$ CLA, and cis-9,trans-11,cis-15 18:3 in milk fat in the absence of altered extraction rate or the extent of FA desaturation in the mammary glands.

Silages resulted in higher concentrations and secretion of 3S,7R,11R,15-tetramethyl-16:0 in milk relative to hay, which is in agreement with several recent reports (Baars et al., 2012; Schröder et al., 2012). In the absence of direct measurements, differences in the enrichment of 3S,7R,11R,15-tetramethyl-16:0 in plasma lipid fractions and milk fat suggest that ensiling results in much lower losses of chlorophyll and (or) phytol compared with the conservation of grass by extensive wilting.

Extent of Silage Fermentation. Restricting fermentation in silo had relatively minor effects on milk fat composition. Use of a formic acid-based additive increased 18:2n- 6 and 18:3n-3 secretion by 13 and $10 \%$, respectively, consistent with numerical, but not significant, increases in the uptake of PUFA across the mammary glands. Secretion of trans-11 18:1 and cis9,trans-11 CLA in milk fat was also increased for FAS compared with UTS, confirming earlier reports (Shingfield et al., 2005). Restricting fermentation in silo resulted in higher milk fat 18:0, trans-9, cis-12 18:2, trans11,cis-15 18:2, and trans-11,cis-13 CLA concentrations, which were accompanied by higher flows of these FA at the omasum (Halmemies-Beauchet-Filleau et al., 2013), whereas increased enrichment of 18-carbon biohydrogenation intermediates appears to reflect the marginally higher intake of PUFA for FAS than UTS, rather than alterations in lipolysis or biohydrogenation in the rumen (Halmemies-Beauchet-Filleau et al., 2013).

\section{CONCLUSIONS}

Feeding diets based on fresh grass, grass hay, or grass silage altered the concentration and composition of plasma lipid fractions. Concentrations of TAG and PL in arterial blood were higher in cows fed fresh grass or grass silages compared with hay. Zero grazing tended to lower positive calculated energy balance, increased NEFA concentrations in arterial blood, and resulted in a higher relative abundance of $18: 2 \mathrm{n}-6$ and $18: 3 \mathrm{n}-3$ in plasma TAG. Fresh grass resulted in higher cis-9 18:1, cis-9,trans-11 CLA, 18:2n-6, and 18:3n-3, and lower 16:0 and total SFA concentrations in milk fat compared 
with hay, changes that were associated with increased uptake of preformed FA and lowered synthesis of FA de novo in the mammary glands. Conservation of grass by ensiling rather than drying increased milk fat synthesis, but had relatively minor effects on the composition of plasma lipids, mammary FA uptake, and milk FA composition. Differences in milk FA composition with fresh grass compared with conserved forages were accompanied by alterations in the composition of plasma lipid fractions and uptake of FA across the mammary glands, in the absence of altered stearoyl-CoA desaturase activity.

\section{ACKNOWLEDGMENTS}

The authors gratefully acknowledge the contribution of staff at the Metabolism Unit of MTT Agrifood Research Finland (Jokioinen, Finland) for the care of experimental animals and the collection of experimental samples under the supervision of Laila Hakkarainen and chemical analysis undertaken in the MTT laboratory under the guidance of Taina Jalava. Valued contributions of Minna Aalto, Tuija Hakala, and Anne Honkanen (MTT Agrifood Research Finland) during lipid analysis are appreciated. This work was supported in part by LIPGENE, a European Union Sixth Framework Programme Integrated Project (2004-2009) (http://www.lipgene.tcd.ie) and a $\mathrm{PhD}$ studentship from the Raisio Science Foundation (Raisio, Finland).

\section{REFERENCES}

Ackman, R. G., and R. P. Hansen. 1967. The occurrence of diastereomers of phytanic and pristanic acids and their determination by gas-liquid chromatography. Lipids 2:357-362.

Agenäs, S., K. Holtenius, M. Griinari, and E. Burstedt. 2002. Effects of turnout to pasture and dietary fat supplementation on milk fat composition and conjugated linoleic acid in dairy cows. Acta Agric. Scand. A Anim. Sci. 52:25-33.

Annison, E. F., J. L. Linzell, and C. E. West. 1968. Mammary and whole animal metabolism of glucose and fatty acids in fasting lactating goats. J. Physiol. 197:445-459.

Baars, T., M. Schröder, D. Kusche, and W. Vetter. 2012. Phytanic acid content and SRR/RRR diastereomer ratio in milk from organic and conventional farms at low and high fodder input. Organic Agric. 2:13-21.

Bauchart, D. 1993. Lipid absorption and transport in ruminants. J. Dairy Sci. 76:3864-3881.

Bendsen, N. T., R. D. K. Christensen, E. M. Bartels, and A. Astrup. 2011. Consumption of industrial and ruminant trans fatty acids and risk of coronary heart disease: A systematic review and metaanalysis of cohort studies. Eur. J. Clin. Nutr. 65:773-783.

Bickerstaffe, R., E. F. Annison, and J. L. Linzell. 1974. The metabolism of glucose, acetate, lipids and amino acids in lactating dairy cows. J. Agric. Sci. (Camb.) 82:71-85.

Cant, J. P., E. J. DePeters, and R. L. Baldwin. 1993. Mammary amino acid utilization in dairy cows fed fat and its relationship to milk protein depression. J. Dairy Sci. 76:762-774.

Chilliard, Y., A. Ferlay, R. M. Mansbridge, and M. Doreau. 2000. Ruminant milk fat plasticity: Nutritional control of saturated, polyunsaturated, trans and conjugated acids. Ann. Zootech. 49:181-205.
Chilliard, Y., F. Glasser, A. Ferlay, L. Bernard, J. Rouel, and M. Doreau. 2007. Diet, rumen biohydrogenation and nutritional quality of cow and goat milk fat. Eur. J. Lipid Sci. Technol. 109:828855.

Christie, W. W. 1981. The effect of diet and other factors on the lipid composition of ruminant tissues and milk. Pages 193-226 in Lipid Metabolism in Ruminant Animals. W. W. Christie, ed. Pergamon Press Inc., Elmsford, NY.

Christie, W. W., R. C. Noble, and R. A. Clegg. 1986. The hydrolysis of very low density lipoproteins and chylomicrons of intestinal origin by lipoprotein lipase in ruminants. Lipids 21:252-253.

Dewhurst, R. J., K. J. Shingfield, M. R. F. Lee, and N. D. Scollan. 2006. Increasing the concentrations of beneficial fatty acids in milk produced by dairy cows in high-forage systems. Anim. Feed Sci. Technol. 131:168-206.

Elgersma, A., S. Tamminga, and G. Ellen. 2006. Modifying milk composition through forage. Anim. Feed Sci. Technol. 131:207-225.

Enjalbert, F., M. C. Nicot, C. Bayourthe, and R. Moncoulon. 1998. Duodenal infusions of palmitic, stearic or oleic acids differentially affect mammary gland metabolism of fatty acids in lactating dairy cows. J. Nutr. 128:1525-1532.

Ferlay, A., B. Martin, Ph. Pradel, J. B. Coulon, and Y. Chilliard. 2006 Influence of grass-based diets on milk fatty acid composition and milk lipolytic system in Tarentaise and Montbéliarde cow breeds. J. Dairy Sci. 89:4026-4041.

Funaki, M. 2009. Saturated fatty acids and insulin resistance. J. Med. Invest. 56:88-92.

Gebauer, S. K., T. L. Psota, W. S. Harris, and P. M. Kris-Etherton. 2006. n-3 Fatty acid dietary recommendations and food sources to achieve essentiality and cardiovascular benefits. Am. J. Clin. Nutr. 83:1526S-1535S.

Glasser, F., M. Doreau, A. Ferlay, J. J. Loor, and Y. Chilliard. 2007. Milk fatty acids: Mammary synthesis could limit transfer from duodenum in cows. Eur. J. Lipid Sci. Technol. 109:817-827.

Glasser, F., A. Ferlay, M. Doreau, P. Schmidely, D. Sauvant, and Y. Chilliard. 2008. Long-chain fatty acid metabolism in relation to duodenal flows and de novo synthesis. J. Dairy Sci. 91:2771-2785.

Halmemies-Beauchet-Filleau, A., P. Kairenius, S. Ahvenjärvi, L. K. Crosley, S. Muetzel, P. Huhtanen, A. Vanhatalo, V. Toivonen, R. J. Wallace, and K. J. Shingfield. 2013. Effect of forage conservation method on ruminal lipid metabolism and microbial ecology in lactating cows fed diets containing a 60:40 forage-to-concentrate ratio. J. Dairy Sci. 96:2428-2447.

Halmemies-Beauchet-Filleau, A., T. Kokkonen, A.-M. Lampi, V. Toivonen, K. J. Shingfield, and A. Vanhatalo. 2011. Effect of plant oils and camelina expeller on milk fatty acid composition in lactating cows fed diets based on red clover silage. J. Dairy Sci. 94:4413-4430

Harfoot, C. G., and G. P. Hazlewood. 1988. Lipid metabolism in the rumen. Pages 285-322 in The Rumen Microbial Ecosystem. P. N. Hobson, ed. Elsevier Applied Sci. Publ., London, UK.

Huhtanen, P. 1998. Supply of nutrients and productive responses in dairy cows given diets based on restrictively fermented silage. $\mathrm{Ag}-$ ric. Food Sci. Finland 7:219-250.

Hulshof, K. F. A. M., M. A. Van Erp-Baart, M. Anttolainen, W. Becker, S. M. Church, C. Couet, E. Hermann-Kunz, H. Kesteloot, T. Leth, I. Martins, O. Moreiras, J. Moschandreas, L. Pizzoferrato, A. H. Rimestad, H. Thorgeirsdottir, J. M. M. van Amelsvoort, A. Aro, A. G. Kafatos, D. Lanzmann-Petithory, and G. van Poppel. 1999. Intake of fatty acids in Western Europe with emphasis on trans fatty acids: The TRANSFAIR study. Eur. J. Clin. Nutr. 53:143-157.

Kaluzny, M. A., L. A. Duncan, M. V. Merritt, and D. E. Epps. 1985. Rapid separation of lipid classes in high yield and purity using bonded phase columns. J. Lipid Res. 26:135-140.

Kay, J. K., J. R. Roche, E. S. Kolver, N. A. Thomson, and L. H. Baumgard. 2005. A comparison between feeding systems (pasture and TMR) and the effect of vitamin E supplementation on plasma and milk fatty acid profiles in dairy cows. J. Dairy Res. 72:322-332.

Kris-Etherton, P. M., D. S. Taylor, S. Yu-Poth, P. Huth, K. Moriarty, V. Fishell, R. L. Hargrove, G. Zhao, and T. D. Etherton. 2000. 
Polyunsaturated fatty acids in the food chain in the United States. Am. J. Clin. Nutr. 71:179S-188S.

Lapierre, H., G. E. Lobley, L. Doepel, G. Raggio, H. Rulquin, and S. Lemosquet. 2012. Triennial Lactation Symposium: Mammary metabolism of amino acids in dairy cows. J. Anim. Sci. 90:17081721.

Leiber, F., M. Kreuzer, D. Nigg, H.-R. Wettstein, and M. R. L. Scheeder. 2005. A study on the causes for the elevated n-3 fatty acids in cows' milk of alpine origin. Lipids 40:191-202.

Lock, A. L., and P. C. Garnsworthy. 2003. Seasonal variation in milk conjugated linoleic acid and $\Delta^{9}$-desaturase activity in dairy cows. Livest. Prod. Sci. 79:47-59.

Lock, A. L., and K. J. Shingfield. 2004. Optimising milk composition. Pages 107-188 in Dairying: Using Science to Meet Consumers' Needs. Br. Soc. Anim. Sci. Publ. 29. E. Kebreab, J. Mills, and D. E. Beever, ed. Nottingham University Press, Loughborough, UK.

Lough, A. K. 1977. The phytanic acid content of the lipids of bovine tissues and milk. Lipids 12:115-119.

Mahfouz, M. M., A. J. Valicenti, and R. T. Holman. 1980. Desaturation of isomeric trans-octadecenoic acids by rat liver microsomes. Biochim. Biophys. Acta 618:1-12.

Miettinen, H. O., and P. Huhtanen. 1997. Effects of silage fermentation and post-ruminal casein supplementation in lactating dairy cows: 2 - Energy metabolites and plasma amino acids. J. Sci. Food Agric. 74:459-468.

Ministry of Agriculture, Fisheries and Food. 1975. Energy allowances and feeding systems for ruminants. Technical Bulletin 33. Ministry of Agriculture, Fisheries and Food, London, UK.

Mohammed, R., R. G. Khorasani, L. A. Goonewardene, J. K. G. Kramer, and J. J. Kennelly. 2011. Persistency of milk trans-18:1 isomers and rumenic acid in Holstein cows over a full lactation. Can. J. Anim. Sci. 91:147-167.

Mohammed, R., C. S. Stanton, J. J. Kennelly, J. K. G. Kramer, J. F. Mee, D. R. Glimm, M. O'Donovan, and M. M. Murphy. 2009. Grazing cows are more efficient than zero-grazed and grass silagefed cows in milk rumenic acid production. J. Dairy Sci. 92:38743893.

Moore, J. H., and W. W. Christie. 1979. Lipid metabolism in the mammary gland of ruminant animals. Prog. Lipid Res. 17:347-395.

Mosley, E. E., and M. A. McGuire. 2007. Methodology for the in vivo measurement of the $\Delta^{9}$-desaturation of myristic, palmitic, and stearic acids in lactating dairy cattle. Lipids 42:939-945.

Mosley, E. E., B. Shafii, P. J. Moate, and M. A. McGuire. 2006. Cis-9, trans-11 conjugated linoleic acid is synthesized directly from vaccenic acid in lactating dairy cattle. J. Nutr. 136:570-575.

MTT Agrifood Research Finland. 2010. Finnish feed tables and feeding recommendations: 2010. Accessed Nov. 20, 2012. https://portal.mtt.fi/portal/page/portal/Rehutaulukot/feed_tables_english/ nutrient_requirements/Ruminants/Energy_dairy_cows.

Noble, R. C. 1984. Essential fatty acids in the ruminant. Pages 185200 in Fats in Animal Nutrition. J. Wiseman, ed. Butterworths, London, UK.

Offer, N. W., B. K. Speake, J. Dixon, and M. Marsden. 2001. Effect of fish-oil supplementation on levels of (n-3) poly-unsaturated fatty acids in the lipoprotein fractions of bovine plasma. Anim. Sci. 73:523-531.

Palmquist, D. L. 1976. A kinetic concept of lipid transport in ruminants. A review. J. Dairy Sci. 59:355-363.

Palmquist, D. L., C. L. Davis, R. E. Brown, and D. S. Sachan. 1969. Availability and metabolism of various substrates in ruminants. V. Entry into the body and incorporation into milk fat of $\mathrm{D}(-)$ $\beta$-hydroxybutyrate. J. Dairy Sci. 52:633-638.

Palmquist, D. L., A. L. Lock, K. J. Shingfield, and D. E. Bauman. 2005. Biosynthesis of conjugated linoleic acid in ruminants and hu- mans. Pages 179-218 in Advances in Food and Nutrition Research. Vol. 50. S. L. Taylor, ed. Elsevier Inc., San Diego, CA.

Roy, A., A. Ferlay, K. J. Shingfield, and Y. Chilliard. 2006. Examination of the persistency of milk fatty acid composition responses to plant oils in cows given different basal diets, with particular emphasis on trans-C18:1 fatty acids and isomers of conjugated linoleic acid. Anim. Sci. 82:479-492.

Schlüter, A., P. Yubero, R. Iglesias, M. Giralt, and F. Villarroya. 2002. The chlorophyll-derived metabolite phytanic acid induces white adipocyte differentiation. Int. J. Obes. Relat. Metab. Disord. 26:1277-1280.

Schröder, M., N. L. Lutz, E. C. Tangwan, E. Hajazimi, and W. Vetter. 2012. Phytanic acid concentrations and diastereomer ratios in milk fat during changes in the cows' feed from concentrate to hay and back. Eur. Food Res. Technol. 234:955-962.

Schröder, M., and W. Vetter. 2011. GC/EI-MS Determination of the diastereomer distribution of phytanic acid in food samples. J. Am. Oil Chem. Soc. 88:341-349.

Scislowski, V., D. Bauchart, D. Gruffat, P. M. Laplaud, and D. Durand. 2005. Effects of dietary n-6 or n-3 polyunsaturated fatty acids protected or not against ruminal hydrogenation on plasma lipids and their susceptibility to peroxidation in fattening steers. J. Anim. Sci. 83:2162-2174.

Shingfield, K. J., M. Bonnet, and N.D. Scollan. 2013. Recent developments in altering the fatty acid composition of ruminant-derived foods. Animal 7(Suppl. 1):132-162. http://dx.doi.org/10.1017/ S1751731112001681.

Shingfield, K. J., Y. Chilliard, V. Toivonen, P. Kairenius, and D. I. Givens. 2008. Trans fatty acids and bioactive lipids in ruminant milk. Pages 3-65 in Bioactive Components of Milk, Advances in Experimental Medicine and Biology. Vol. 606. Z. Bösze, ed. Springer, New York, NY.

Shingfield, K. J., S. Jaakkola, and P. Huhtanen. 2002a. Effect of forage conservation method, concentrate level and propylene glycol on intake, feeding behaviour and milk production of dairy cows. Anim. Sci. 74:383-397.

Shingfield, K. J., S. Jaakkola, and P. Huhtanen. 2002b. Effect of forage conservation method, concentrate level and propylene glycol on diet digestibility, rumen fermentation, blood metabolite concentrations and nutrient utilisation of dairy cows. Anim. Feed Sci. Technol. 97:1-21.

Shingfield, K. J., P. Salo-Väänänen, E. Pahkala, V. Toivonen, S. Jaakkola, V. Piironen, and P. Huhtanen. 2005. Effect of forage conservation method, concentrate level and propylene glycol on fatty acid composition and vitamin content of cows' milk. J. Dairy Res. $72: 349-361$

Thivierge, M. C., Y. Chouinard, J. Lévesque, V. Girard, J. R. Seoane, and G. J. Brisson. 1998. Effect of buffer on milk fatty acids and mammary arteriovenous differences in dairy cows fed Ca salts of fatty acids. J. Dairy Sci. 81:2001-2010.

Tyburczy, C., A. L. Lock, D. A. Dwyer, F. Destaillats, Z. Mouloungui, L. Candy, and D. E. Bauman. 2008. Uptake and utilization of trans octadecenoic acids in lactating dairy cows. J. Dairy Sci. 91:3850-3861.

Verhoeven, N. M., R. J. A. Wanders, D. S. M. Schor, G. A. Jansen, and C. Jakobs. 1997. Phytanic acid $\alpha$-oxidation: Decarboxylation of 2-hydroxyphytanoyl-CoA to pristanic acid in human liver. J. Lipid Res. 38:2062-2070.

WHO (World Health Organization). 2003. Diet, nutrition and the prevention of chronic diseases. Report of a joint WHO/FAO expert consultation. WHO technical report series No. 916. WHO, Geneva, Switzerland. 